This PDF is a selection from an out-of-print volume from the National Bureau of Economic Research

Volume Title: The Role of Direct and Indirect Taxes in the Federal Reserve System

Volume Author/Editor: NBER and The Brookings Institution

Volume Publisher: Princeton University Press

Volume ISBN: 0-87014-469-3

Volume URL: http://www.nber.org/books/unkn64-4

Publication Date: 1964

Chapter Title: Comparison of European and United States Tax Structures and Growth Implications

Chapter Author: Otto Eckstein, Vito Tanzi

Chapter URL: http://www.nber.org/chapters/c1876

Chapter pages in book: (p. 217 - 293) 


\title{
Comparison of European and United States Tax Structures and Growth Implications
}

\author{
OTTO ECKSTEIN ASSISTED BY VITO TANZI
}

\author{
HARVARD UNIVERSITY
}

THIs paper has a very limited objective: to set forth, in summary form, the chief characteristics of the tax systems of the major European countries. This summary is designed to serve as a background for the main issue of this Conference--the proper division between direct and indirect taxes in the American tax system. A factual account is important because European tax systems and high rates of European growth are the arguments the most frequently invoked in favor of revamping our own tax system. It is my belief that this argument is based upon a somewhat idealized picture of European tax systems.

I shall also make some comments about the relations of European tax systems to the successful growth experienced by the continental countries in the last fifteen years. But let me make clear that the systematic study of European growth is only in its infancy. To my knowledge, there is at present no scientific analysis which explains the favorable growth performance, that is, no set of hypotheses confirmed by statistical tests absorbing the major economic data. In the absence of a scientific understanding of European growth, it is impossible to reach firm conclusions about the effects of European tax systems, for propositions about the effects of tax systems on the performance of economies are no more than corollaries to theories explaining the be havior of the particular economic systems.

The factual examination will proceed in two stages: First, summary statistics on direct and indirect taxation are analyzed. The definitional problems here turn out to be quite serious. Second, a breakdown of the direct and indirect taxes into the major subtypes of taxes is given and some comparisons are made. Finally, a view of European growth is given and conjectures offered on the role of tax policy in the growth process. An appendix, prepared by Vito Tanzi, summarizes the tax systems in greater detail and draws further comparisons. To put some limit to the scope of this paper, the analysis is confined to France, Germany, Italy, the United Kingdom, and the United States. Some 
figures are also given for Japan, another major noncommunist, industrial country, and the reigning growth champion. While some interest attaches to the tax systems of the smaller countries, particularly their more novel devices, their economic structures so differ from our own that comparative study is less profitable.

The international comparison of tax systems is indeed a treacherous task. The actual burden of taxation depends not only on the letter of the law-which is complicated enough - but also on the spirit of compliance and enforcement. Every major tax system has its history of erosion, of preferential treatment, and even of dead letters. A perfect comparison can only be obtained by living under each of the tax systems and by dealing with each of the tax collectors. Nevertheless, this paper is offered in the belief that a comparison of some of the salient characteristics of the nominal tax systems, together with some statistically derived measures of burden, can be of use.

\section{Direct vs. Indirect Taxation: Some Crude Numerical Arguments}

We are all familiar with the following argument: High-growth continental countries rely far less on direct taxes than on indirect taxes. Their rapid growth is due to the high rate of saving made possible by this heavy reliance on indirect taxes. The United States and the United Kingdom, on the other hand, rely more heavily on direct taxes, save. less, and grow less. ${ }^{1}$

Table 1 presents the statistical argument in its crudest form. The American share of direct income taxes appears to be completely out of line with every other country, and, in the light of our inferior growth performance, would lead almost anyone to question whether our tax system is a sunsible one.

However, as Fellner has pointed out, ${ }^{2}$ there are no universally accepted definitions of direct and indirect taxes. The much-quoted comparison given in Table 1 is based on a concept of direct taxes which includes

${ }^{1}$ This argument has been advanced, for example, by Governor Rockefeller in his address to the NAM Congress on Economic Problems, reported in the New York Times, December 6, 1962; by Life magazine in an editorial; by Professor Henry C. Wallich in the New York Times Magazine (September 9, 1962, p. 27) "For Fastest Growth-What Kind of Tax?"; and by Professor William Fellner, "Problems of Public Finance During the Sixties," Research Study No. 1 prepared for the Commission on Money and Credit, published in Fiscal and Debt Management Policies, Englewood Cliffs, 1963. Professor Fellner presents figures on various alternative statistical concepts; the other sources rely on figures of the type presented in Table 1.

2 Ibid., pp. 38-44. 
TABLE 1

DIRECT PERSONAL AND CORPORATE INCOME TAX YIELDS AS A PERCENTAGE OF TOTAL TAX COLLECTIONS OF CENTRAL GOVERNMENTS ONLY, SAVINGS RATES, AND GROWTH RATES

\begin{tabular}{lccc}
\hline \hline & $\begin{array}{c}\text { Direct } \\
\text { Income Taxes } \\
\text { as Per Cent of } \\
\text { All Taxes, 1960 }\end{array}$ & $\begin{array}{c}\text { Savings as } \\
\text { Per Cent of GNP, } \\
\text { 1950-60, } \\
\text { Average }\end{array}$ & $\begin{array}{c}\text { Annual Average } \\
\text { Rate of Growth } \\
\text { of Real GNP, } \\
1950-60\end{array}$ \\
\hline & & & \\
France & 33 & 21 & 4.3 \\
Germany & 43 & 25 & 7.5 \\
Italy & 19 & 23 & 5.9 \\
Japan & 59 & 26 & 8.8 \\
United Kingdom & 51 & 17 & 2.6 \\
United States & 80 & 18 & 3.3 \\
\hline
\end{tabular}

Source: Based on official statistics of the countries in Appendix Tables 14-18.

only personal and corporate income taxes, and is thus much narrower than the more commonly accepted concept. It may be worthwhile discussing whether the United States has too much income taxation, but this is a different issue from that of direct vs. indirect taxation under the usual definitions. A further limitation of the figures is that they cover central government revenues only, excluding state and local taxes.

After a search of the literature, I find that the definition employed in the standardized system of national accounts prepared by Professor Richard Stone for the OEEC and employed by many countries around the world today has perhaps the most authority. There ${ }^{3}$ direct taxes on corporations are defined as "those which are regularly levied on income or capital (that is, assets minus debts) the assessment of which will normally take into account the individual circumstances of the taxpayer. ... The taxes in this flow comprise payables by incorporated enterprises and co-operatives such as corporate taxes, excess profits taxes and taxes on undistributed profits or on the capital of corporations." Direct taxes on households, etc., include "all payables by households and private nonprofit institutions in respect of direct taxes, as defined . . . above, such as income taxes, surtaxes etc. In addition, all social security contributions are included in this item. All taxes charged on the possession or use of various durable goods by households are excluded from this flow and included as indirect taxes . .."

Thus, according to this definition direct taxes are the sum of income

${ }^{3} A$ Standardized System of National Accounts, OEEC, 1958 ed., pp. 83 and 86 
taxes, estate and gift taxes, personal capital taxes, and all social security contributions. Table 2 is based on the OEEC definitions. The figures for the countries other than the United States become substantially larger than those in Table 1, although they are still far from the extreme results obtained for the United States.

TABLE 2

DIRECT TAXES BY MAJOR CATEGORIES AS A PERCENTAGE OF TOTAL TAXES, CENTRAL GOVERNMENTS ONLY

\begin{tabular}{|c|c|c|c|c|c|}
\hline $\begin{array}{l}\text { Personal } \\
\text { Income } \\
\text { Taxes }\end{array}$ & $\begin{array}{l}\text { Corporate } \\
\text { Income } \\
\text { Taxes }\end{array}$ & $\begin{array}{l}\text { Capital, } \\
\text { Estate, } \\
\text { and Gift } \\
\text { Taxes }\end{array}$ & $\begin{array}{c}\text { Social } \\
\text { Security } \\
\text { Contri- } \\
\text { butions }\end{array}$ & other & $\begin{array}{l}\text { Total } \\
\text { Direct } \\
\text { Taxes }\end{array}$ \\
\hline
\end{tabular}

\begin{tabular}{|c|c|c|c|c|c|}
\hline France $c$ & $\begin{array}{l}11 \\
22\end{array}$ & 7.2 & .8 & $\begin{array}{l}38 \\
32\end{array}$ & $5.1^{b}$ \\
\hline Italy & 2 & 0. & 1.1 & 34 & 2.3 \\
\hline Japan & 19 & 29 & .6 & 19 & \\
\hline United Kingdom & 31 & 11 & 3.6 & 14 & \\
\hline United States & 45 & 22 & 1.8 & 18 & \\
\hline
\end{tabular}

Source: Based on official statistics of the countries in Appendix Tables 14-18.

ancludes social security contributions.

bersement forfaitaire (payroll tax paid by employer on salaries and wages).

CIncludes Lunder.

These figures are for central governments only. In the case of France, Italy, and the United Kingdom, central government revenues are a very large fraction of total government revenues, since local revenues are rather small. But Germany and the United States have federal systems of government, and relatively important local revenues. In the United States, indirect taxes constitute 87 per cent of revenues at the state and local levels. Therefore, the comparative figures change drastically when all levels of government rather than central governments alone are considered. Table 3 shows the comparison of direct taxes as a percentage of total taxes for all levels of government (called "general government" in the statistical sources), using the official OEEC definitions.

On this basis, which is the most satisfactory one as long as the argument is confined to crude statistical comparisons of direct and indirect taxes, the United States figures are only moderately out of line with those of other countries. If the proposed tax program is enacted (cutting 
TABLE 3

DIRECT TAXES INCLUDING SOCIAL SECURITY CONTRIBUTIONS AS A PERCENTAGE OF TOTAL TAXES, ALL LEVELS OF GOVERNMENT, 1961

\begin{tabular}{ll}
\hline \hline France & 52 \\
Germany & 59 \\
Italy & 51 \\
United Kingdom & 53 \\
United States & 66 \\
\hline
\end{tabular}

Source: OEEC statistics, 1962.

personal and corporate income taxes by 16 per cent $\left.{ }^{4}\right)$, the U.S. figure will fall to about 63 per cent, a few points above Germany, about 10 points above the others.

A better measure of the burden of direct taxation can be obtained by comparing direct-tax revenues with some measure of income, such as national income or gross national product, rather than with total tax revenues. Total taxes are a larger fraction of GNP in the European countries, despite their much smaller outlays for defense, because of a higher level of welfare expenditures. In the comparison of direct taxes as a percentage of GNP for all levels of government (Table 4), American direct taxes including social security contributions are a slightly larger fraction of GNP than such taxes are in Italy and the United Kingdom, about the same as in France, and lower than in Germany. ${ }^{5}$

But these are just numerical debating points and all $I$ have attempted to do so far is to report the figures as they would appear following the official OEEC definition. I agree with Fellner that the official definition of direct taxes is too broad at least for the specific economic analysis at issue here. The definitions of direct and indirect taxation can be based on various criteria, which are discussed in Due's introduction to this volume and in some of the papers. The distinction can be made on such grounds as tax-consciousness, shiftability, personal assessment as opposed to levies on transactions, and income as opposed to expenditures. For the purposes of this paper, I take the issue to be the following: do direct taxes, by being a payment to the government wholly related to individual income or wealth, discourage private effort, saving, and investment? The requisite definition must be partly based on taxconsciousness and partly on the initial impact falling on income rather than consumption.

\footnotetext{
${ }^{4}$ Reference to tax reduction proposals are to those which were enacted in March 1964.

${ }^{5}$ If social security contributions are excluded, the U.S. figure becomes the highest, but after the tax cut would differ little from Germany and the United Kingdom
} 
TABLE 4

DIRECT TAXES, EXCLUDING AND INCLUDING SOCIAL SECURITY CONTRIBUTIONS, AS A PERCENTAGE

OF GNP AND TOTAL TAXES AS A PERCENTAGE OF GNP, ALL LEVELS OF GOVERNMENT, 1961

\begin{tabular}{|c|c|c|c|}
\hline & \multirow[b]{2}{*}{$\begin{array}{l}\text { Total Taxes } \\
\text { as Per Cent } \\
\text { of GNP }\end{array}$} & \multicolumn{2}{|c|}{ Direct Taxes as Per Cent of GNP } \\
\hline & & $\begin{array}{c}\text { Excluding } \\
\text { Social } \\
\text { Security } \\
\text { Contributions }\end{array}$ & $\begin{array}{c}\text { Including } \\
\text { Social } \\
\text { Security } \\
\text { Contributions }\end{array}$ \\
\hline France & 35 & 6 & 18 \\
\hline Germany & 35 & 11 & 21 \\
\hline Italy & 28 & 6 & 14 \\
\hline United Kingdom & 29 & 11 & 15 \\
\hline United States & 28 & 14 & 18 \\
\hline U.S. (with tax cut) & 26 & 12 & 16 \\
\hline
\end{tabular}
1962.

Source: UN Yearbook of National Accounts, 1962, and OEEC statistics,

I believe that the following taxes should be properly included as direct according to this approach: all income taxes, estate and gift taxes, and net worth taxes, as well as those social security contributions which are paid by the employee out of his income and based on the amount of that income. This definition differs from the official OEEC definition by excluding employer contributions to social security. I believe that these should be considered indirect taxes because they are costs of carrying on business like any other tax on the use of a factor of production; even if they are shifted to the employee, he will not recognize them nor view them as a direct payment out of his income. Employee contributions to social security are included as a direct tax, however, since they are direct payments by individuals based on their income. Under modern withholding systems, as in the United States, the money withheld for social security from the employee's pay envelope is a direct reduction of his income, in the same fashion as a personal income tax. Presumably it has the same effect on willingness to work and to save. ${ }^{6}$

Table 5 presents comparative figures for the five countries for direct taxes according to this definition, expressed both as a percentage of total government revenue and as a percentage of GNP. In these figures, which I shall take as definitive, the United States has the highest burden

${ }^{6}$ But employee social security contributions do have the desirable properties of a lump-sum tax once income is beyond the level at which the contribution ceiling applies. The marginal rate then becomes zero. 
TABLE 5

DIRECT TAXES, INCLUDING ONLY EMPLOYEE CONTRIBUTIONS TO

SOCIAL SECURITY, AS A PERCENTAGE OF GNP AND AS A

PERCENTAGE OF TOTAL GOVERNMENT REVENUE, ALL LEVELS OF GOVERNMENT, 1961

\begin{tabular}{|c|c|c|c|c|c|}
\hline & $\begin{array}{c}\text { Direct } \\
\text { Taxes } \\
\text { on Persons a } \\
\text { (as }\end{array}$ & $\begin{array}{l}\text { Direct } \\
\text { Taxes on } \\
\text { Corpo- } \\
\text { rations } \\
\text { per cent }\end{array}$ & $\begin{array}{c}\text { Employee } \\
\text { Contri- } \\
\text { butions } \\
\text { to Social } \\
\text { Security } \\
\text { of total }\end{array}$ & $\begin{array}{l}\text { Total } \\
\text { Direct } \\
\text { Taxes } \\
\text { taxes) }\end{array}$ & $\begin{array}{r}\text { Total Direct } \\
\text { Taxes as Per } \\
\text { Cent of GNP }\end{array}$ \\
\hline \multicolumn{6}{|c|}{$\cdot$} \\
\hline Erance & 11 & 7 & 9 & 27 & 9 \\
\hline Germany & 22 & 9 & 13 & 44 & 15 \\
\hline Italy & 2 & $-21-$ & 6 & 27 & 8 \\
\hline United Kingdom & 29 & 11 & 6 & 46 & 13 \\
\hline United States & 36 & 15 & 7 & 57 & 16 \\
\hline
\end{tabular}

\footnotetext{
${ }^{a}$ OEEC statistics, 1962.

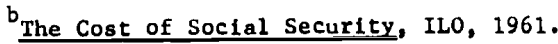

c Survey of Current Business, July 1962.
}

of direct taxation in relation to GNP, slightly greater than Germany, somewhat greater than the United Kingdom, much greater than France or Italy. The tax cut would bring the U.S. figures to about the level of Germany and the United Kingdom.

\section{Comparison of Specific Taxes}

The aggregate statistics are of some significance as measures of the tax burden. However, the total revenue figures depend upon the nominal rate structure; the absolute levels of income, in the case of progressive income taxes; the extent of loopholes, tax avoidance, and evasion; the relative size of the agricultural sector; and the importance of unincorporated business.

To dig a little deeper into the problem, I now present some comparisons for each of the major direct and indirect taxes for the five countries.

\section{A. DIRECT TAXES}

\section{Personal Income Taxes}

All the five countries have progressive income taxes. Comparison is difficult because the taxes differ not only in rates, but also in other aspects of their structure, such as the treatment of the family, of capital gains, and of income from different sources. Thus, Italy has a schedular 
income tax in addition to a global tax; the United Kingdom is particularly unfavorable in its tax treatment of marriage, while France has a system of income splitting even more elaborate than the United States and Germany. The Appendix contains a summary of the structural features of the income taxes. Here I shall only draw some numerical comparisons, which, however, suffice to bring out the relative income tax burdens.

Table 6 gives some characteristics of the rate structures. It shows,

TABLE 6

CHARACTERISTICS OF

UPPER AND LOWER LEVELS OF PERSONAL INCOME TAX

STRUCTURES, FOR MARRIED COUPLES WITH TWO

CHILDREN, CENTRAL GOVERNMENTS, ${ }^{1961}$

\begin{tabular}{lccccc}
\hline \hline & $\begin{array}{c}\text { Total } \\
\text { Exemption } \\
\text { (dollars) }\end{array}$ & $\begin{array}{c}\text { First } \\
\text { Bracket } \\
\text { Rate } \\
\text { (per cent) }\end{array}$ & $\begin{array}{c}\text { Limit of } \\
\text { First } \\
\text { Bracket } \\
\text { (dollars) }\end{array}$ & $\begin{array}{c}\text { Maximum } \\
\text { Marginal Rate } \\
\text { (per cent) }\end{array}$ & $\begin{array}{c}\text { Income Level } \\
\text { at Which Maximum } \\
\text { Rate Is Reached } \\
\text { (dollars) }\end{array}$ \\
\hline & & & & & \\
France & 42 & 5 & 1,380 & 52.8 & 45,640 \\
$\begin{array}{l}\text { Germagny } \\
\text { Italy }\end{array}$ & 1,560 & 20 & 4,000 & 53 & 52,920 \\
United Kingdome & 1,540 & 4 & 240 & 58 & 800,000 \\
United States & 2,400 & 20 & 280 & 88.75 & 42,842 \\
\hline
\end{tabular}

${ }^{a}$ At official exchange rates as of 1963.

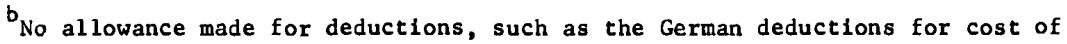
earning a living.

CIncluding Lănder.

dincome from employment.

U.K., after 1963 changes.

for a married taxpayer with two young children, the total exemptions, the lowest rate of tax, the maximum marginal rate, and the income level at which this latter rate begins to apply. It can be seen that all of the European countries have lower exemptions. France and Italy have very much lower exemptions, but their first bracket rates are also lower. Thus, they have less discontinuity between the exemption and the first taxable bracket than the United States. At the other end of the income scale, the maximum marginal rate of tax has been highest in the United States, substantially higher than in the continental countries. After the tax cut, the U.S. rate will still be higher, but the differential will be very much reduced. On the other hand, the maximum rate be- 


\section{EUROPEAN AND U.S. TAX STRUCTURES}

comes applicable at lower income levels in most of the continental countries.

A systematic comparison of the extent of progression among countries requires that a specific set of circumstances be postulated for a family and their hypothetical tax be computed at different income levels. Such an exercise was conducted by L. Needleman of the National Institute of Economic and Social Research. Table 7 summarizes his findings.

TABLE 7

PERCENTAGE OF GROSS INCOME PAID IN TAX AND NET

SOCIAL SECURITY CONTRIBUTIONS ${ }^{\mathrm{a}}$ BY THE

"STANDARD FAMILY," 1960

\begin{tabular}{|c|c|c|c|c|c|c|c|}
\hline \multicolumn{2}{|c|}{ Income Before Tax } & \multirow[b]{2}{*}{ France } & \multirow[b]{2}{*}{ Germany } & \multirow[b]{2}{*}{ Italy } & \multirow[b]{2}{*}{$\begin{array}{l}\text { United } \\
\text { KIngdom }\end{array}$} & \multirow[b]{2}{*}{$\begin{array}{l}\text { United } \\
\text { States }\end{array}$} & \multirow{2}{*}{$\begin{array}{c}\text { U.S. } \\
\text { After } \\
\text { Tax Cut }\end{array}$} \\
\hline $\begin{array}{l}\text { Pounds } \\
\text { Sterling }\end{array}$ & Dollars ${ }^{c}$ & & & & & & \\
\hline $\begin{array}{r}500 \\
1,000 \\
2,000 \\
5,000 \\
10,000 \\
50,000\end{array}$ & $\begin{array}{r}1,705 \\
3,410 \\
6,820 \\
17,050 \\
34,100 \\
170,500\end{array}$ & $\begin{array}{l}0 \\
0 \\
0_{\mathrm{e}}^{\mathrm{e}} \\
13 \\
23 \\
40\end{array}$ & $\begin{array}{l}12 \\
18 \\
18 \\
25 \\
33 \\
48\end{array}$ & $\begin{array}{r}0 \\
5 \\
14 \\
23 \\
30 \\
40\end{array}$ & $\begin{array}{r}1 \\
10 \\
19 \\
36 \\
52 \\
81\end{array}$ & $\begin{array}{r}3 \\
7 \\
10 \\
19 \\
29 \\
62\end{array}$ & $\begin{array}{r}4 \\
6 \\
8 \\
16 \\
24 \\
53\end{array}$ \\
\hline
\end{tabular}

Source: L. Needleman, "International Comparisons of the Burden of Taxation," National Institute Economic Review, March 1961. Figures for France and Italy prepared by Needleman for E. Kirschen and others, Economic Policy in Our Time.

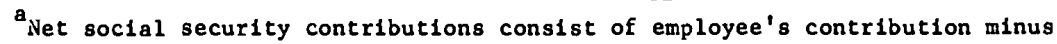
family allowances.


is not a director of a company nor employed in government service, a dependent wife, both adults being under 50 years old, and two children between the ages of 6 and 10 . $c_{\text {At }}$ cost-of-living exchange rates.

$d_{U}$. S. Treasury estimate of effect of tax cut. Increase in lowest bracket is due to rise of social security contributions.

e Less than 0.5 per cent.

Lower-income groups appear to be taxed most heavily in Germany and the U.S.; this is due to the net social security contributions, that is, the receipt of family allowances in the other countries. The burden of taxation on middle- and upper-income groups is highest in the United Kingdom. ${ }^{7}$ The burden in the United States is most nearly comparable to that in Germany, somewhat lower in the lower- and middle-income

${ }^{7} \mathrm{I}$ have not incorporated the effects of the tax reduction in the U.K. in 1963 into the figures. However, the cut was largely a flat amount for all income levels, so that it would not reduce the middle- and upper-income tax rates significantly, but would affect the rates at the bottom. 
brackets, somewhat higher in the high brackets; after the U.S. tax cut, most of the present differential in the tax brackets will be removed. The income tax burden in France and Italy is lower than in the other countries.

The comparison by Needleman utilizes the nominal tax rates. This method makes no allowance for avoidance and evasion or peculiarities of the systems. The tax treatment of capital gains is probably the most important peculiarity to be considered. We know that in the United States the average effective tax rates computed on income inclusive of capital gains are substantially lower than the nominal rates. In fact, they do not go over 40 per cent for any income class. I am not able to estimate the significance of capital gains for the European rich. However, the tax treatment is even more favorable. Capital gains are not taxed at all unless they originate from a personal business. The definition of capital gains excludes some of the fringe areas allowed in the United States, but this is a minor factor compared to the absence of any tax on the capital gains on securities and other assets.

No reliable information is available on the extent of avoidance and evasion. It is generally believed that there is extensive evasion in countries with a Latin tradition such as France and Italy. Some crude idea of the actual burden of income taxes can be obtained from a comparison of the personal income tax payments in relation to national income (see Table 8). The figures imply that there are indeed deviations between the nominal rate structures and the tax revenues collected, but the deviations are not as large as is often suggested. France and Italy collect between 4 and 5 per cent of national income as tax; Germany and the United Kingdom, with substantially higher rate structures, between 8 and 10 per cent. The U.S. figure, which presently is above the rest, will fall to about 9 per cent when the tax cut is enacted.

One would expect that the U.S. income tax would take a larger fraction of income because of the substantially higher level of per capita income. In fact, it is surprising that the differential between the U.S. figure and the others is so small. Given the extent of progression in the tax, a decline of U.S. per capita income to the European levels should result in a far more than proportionate decline in tax collections. If our personal income tax has an income elasticity of 1.5 to 2.0 , then a 30 per cent reduction of per capita income would reduce the ratio of tax to income from 10 per cent to the range of 6 to 8 per cent.

The various comparisons of personal income taxes suggest that Ger- 
TABLE 8

RATIO OF PERSONAL DIRECT TAXES TO NATIONAL INCOME (EXCLUDING SOCIAL SECURITY CONTRIBUTIONS), CENTRAL GOVERINMENTS ONLY, 1960 (per cent)

\begin{tabular}{lr}
\hline \hline France a & 4.3 \\
Germanyy & 8.7 \\
Italy & 5.0 \\
United Kingdog c & 10.0 \\
United States & 10.2 \\
\hline
\end{tabular}

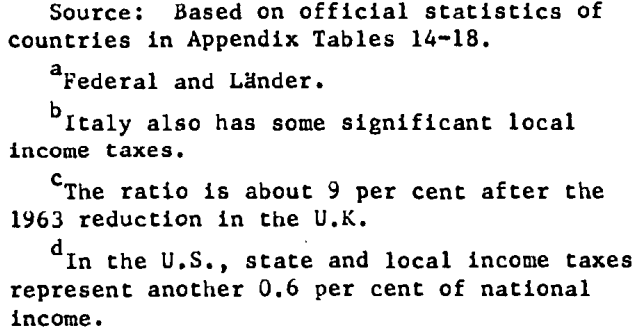

many and the United States have rather similar systems, that the United Kingdom has a system which is more progressive, with lower burdens at the bottom but higher burdens in the middle and upper brackets, and that France and Italy have considerably lighter burdens at the top and bottom, but rather similar burdens to those of the U.S. and Germany in a wide middle range.

\section{Succession, Gift, and Personal Capital Taxes}

The structures of succession and gift taxes vary substantially among the five countries. On the continent, inheritance taxes prevail, with the rates dependent upon the degree of relationship between the deceased and the beneficiary. The United Kingdom and the United States have estate taxes.

Nortcliffe has computed the hypothetical tax payable on an estate of $£ 1,000,000$, that is, $\$ 2,800,000$ (see Table 9 ). Judged by these nominal rates, the succession taxes are very heavy in Italy and the U.K., relatively light in the other three countries. However, avoidance of succession duties is such a common practice that one cannot take the nominal rates as indicative of burdens. Actual revenues are probably a better measure. Table 10 shows the ratios of succession and gift taxes to total taxes and to GNP. Here it can be seen that the United Kingdom has much the heaviest such taxes, that France and Italy and the United 


\section{EUROPEAN AND U.S. TAX STRUCTURES}

TABLE 9

SUCCESSION AND GIFT TAXES PAYABLE ON ESTATE OF $\$ 2,800,000^{2}$ (per cent)

\begin{tabular}{ll}
\hline \hline France & 14 \\
Germany & 10 \\
Italy & 62 \\
United Kingdom & 75 \\
United States & 22 \\
\hline
\end{tabular}

Source: E. B. Nortcliffe, Common Market Fiscal Systems, London, 1961, p. 87.

\section{a}

The table is calculated on the assumption that the property is worth $t 1$ million $(\$ 2,800,000)$, 40 per cent of which is passed to the widow, 15 per cent to each of three sons and daughters, and 5 per cent each to three brothers and sisters. (U.S. estimate by the author.)

States have comparable payments, and Germany has a much lighter burden. ${ }^{8}$

Germany's very light succession duties are offset by her personal net worth tax (Vermögensteuer). This tax is .75 to 1 per cent of the net worth

\section{TABLE 10}

SUCCESSION AND GIFT TAXES AS A PERCEINTAGE OF TOTAL TAXES AND OF GNP, ALL LEVELS OF GOVERNMENT, 1960

\begin{tabular}{lcc}
\hline \hline & $\begin{array}{c}\text { Per Cent of } \\
\text { Total Taxes }\end{array}$ & $\begin{array}{c}\text { Per Cent } \\
\text { of GNP }\end{array}$ \\
\hline & & \\
France & 1.2 & 0.42 \\
Germany & 0.2 & 0.07 \\
Italy & 1.1 & 0.31 \\
United Kingdom & 4.4 & 1.28 \\
United States & 1.5 & 0.42 \\
\hline
\end{tabular}

Source: Based on of ficial statistics of countries in Appendix Tables 14-18.

of an individual or a corporation. While assessed rather lightly on real property, it is a significant tax on intangible property, yielding a total revenue equal to 1.93 per cent of all government revenues. There is presently some agitation to increase the rate significantly.

${ }^{8} \mathrm{Gift}$ taxes are consistent with the estate taxes, with either the same or a somewhat lower rate schedule. 
This group of taxes, which can be assumed to fall on personal capital, represents a moderate and similar burden in all countries, except in the United Kingdom where it plays a larger role.

\section{Corporation Income Taxes}

The United States relies more heavily on the corporation income tax than the major European countries. Table 11 shows the relation of the

TABLE 11

CORPORATE INCOME TAXES AS A PERCENTAGE OF GNP AND OF TOTAL TAXES, 1961

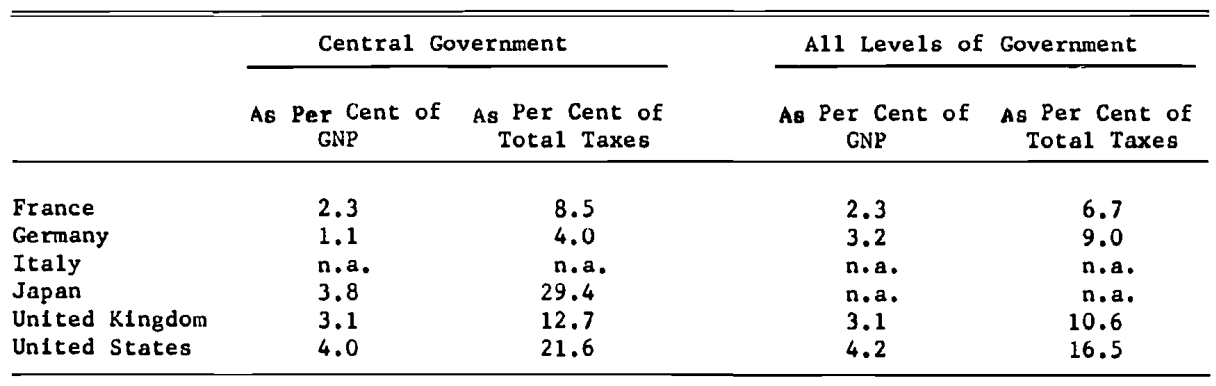

Source: Based on official statistics of countries in Appendix Tables 14-18, and OEEC statistics.

corporation income taxes of the central government and all levels of government to GNP and to total taxes.

The basic nominal rate in the United States is not much higher than elsewhere. But the structures of the taxes differ, particularly in the treatment of distributed profits. The United Kingdom has traditionally followed a policy of integrated treatment of personal and corporate income taxation, and the basic rate of 38.75 per cent is considered withholding at the source on personal tax. There is also a profits tax of 15 per cent, making the tax on undistributed profits equal to 53.75 per cent and that on distributed profits only 15 per cent. Germany, in order to foster the development of a capital market rather than have companies rely exclusively on internal financing, has a tax rate on undistributed profits of 51 per cent, but on distributed profits of only 15 per cent. France, like the United States, does not distinguish between distributed and undistributed profits and taxes them at 50 per cent. Italy applies its schedular income tax system to corporations as well as individuals, with a maximum rate of 31.23 per cent. In addition, Italy has a corporation tax of 15 per cent on profits exceeding 6 per cent of net 
worth plus a property tax of .75 per cent on net worth. These two taxes together normally produce a total tax of about 45 per cent on profits; however, there is some relief on personal taxation because none of the schedular income taxes applies to the dividend income, which is subject only to the global tax.

Depreciation is now on a liberal basis in all the countries. In France, the declining-balance method was approved in 1959, as a replacement for numerous special provisions including escalation for inflation; 9 it will be compulsory after 1964. In Germany, the declining-balance method is a standard method. In Italy, the straight-line method is still standard but the permissible rates are fairly liberal; investment in the south of the country and in new industries benefits from special treatment. The United Kingdom still does not permit universal use of the declining-balance method, particularly for buildings, but liberal use has been made of investment allowances, which grant additional depreciation deductions in the early years. The United States not only permits the use of the declining-balance and sum-of-the-year-digit methods but has also instituted an investment credit of 7 per cent on equipment, and has shortened the periods over which particular assets may be fully depreciated. Given the extent of administrative discretion in the setting of depreciation allowances, it is difficult to compare the actual practices of the various countries. However, after the several liberalizing depreciation moves in the U.S., it would be hard to argue that our practice is significantly tougher than elsewhere.

Given the rather general similarities of nominal rates and practices, why does the American corporation income tax represent a higher percentage of GNP than in the other countries? The primary reason lies in the greater significance of the corporate sector in the economy. In the U.S., 65 per cent of national income originates in the corporate sector; in the European countries the figure is one-half or less. The remaining differences are due to: (1) the lower rates on distributed profits, i.e., in Germany, the United Kingdom; (2) a lower professional standard of accounting; (3) time lags in the collection of taxes in an expanding economy (a time lag of two years is not unusual in Europe, compared to a present lag of six months in the United States); and (4) administrative interpretations which may be more favorable in some European countries than here.

\footnotetext{
${ }^{9}$ See Martin Norr, "Depreciation Reform in France," in Taxes-The Tax Magazine, May 1961, pp. 391-401, for a description of the important and instructive changes that were made in this area in France.
} 


\section{EUROPEAN AND U.S. TAX STRUCTURES}

\section{Other Direct Taxes on Business Income}

This discussion of direct taxation would not be complete without mentioning other significant direct taxes on business. Particularly in Germany, the direct burden on business includes other taxes as well as the income tax. The property tax (Vermögensteuer) of 1 per cent of net worth adds to the burden. Even more important, the trade tax (Gewerbesteuer), which is imposed by municipalities and constitutes their main source of revenue, has a total yield equal to the corporation tax, though part of this is derived from unincorporated business. It provides a 15 per cent tax on profits, a 0.6 per cent tax on net worth, and a 1 to 2 per cent tax on wages paid. ${ }^{10}$

TABLE 12

DIRECT CORPORATION TAXES ON PROFITS AND PROPERTY AS A PERCENTAGE OF NET PROF $1 T^{\mathrm{a}}$

\begin{tabular}{llcc}
\hline \hline & \multicolumn{3}{c}{$\begin{array}{c}\text { Percentage of } \\
\text { Net }\end{array}$} \\
\cline { 2 - 4 } & 0 & 40 & 100 \\
\hline & & & \\
France & 50 & & \\
Germany & 70 & 50 & 50 \\
Italy & 45 & 65 & 53 \\
United Kingdom & 54 & 45 & 45 \\
United States & 55 & 45 & 24 \\
& & 55 & 55 \\
\hline
\end{tabular}

\footnotetext{
Source: R. Mees and Zoonen, Company Taxation in Western Europe, 1962, p. 7, U.S. estimate made by the author.

a

The table makes no allowance for value-added taxes which are classified in the indirest category. They will be discussed at greater length below. But let me point out here that the French value-added tax of 20 per cent applies to all of the value-added, including corporate profits. Thus the tax has some of the characteristics of a direct tax of 20 per cent on all profits.
}

A well-known study by the International Bureau of Fiscal Documentation in Amsterdam presents comparative figures of direct-tax burdens on profits and property of corporations for the European countries, considering both income and other direct taxes (see Table 12). ${ }^{11}$ This

${ }^{10}$ Minor direct taxes on business can also be found in France and Italy.

${ }^{11}$ Also see the paper by Musgrave and Richman in this volume for a more recent comparison. 
table shows that the burden is heaviest in Western Germany, particularly if a substantial portion of profits are retained in the business. France, Italy, and the United Kingdom all have burdens of about 50 per cent. Figures for the United States are bit higher than for the latter group when state taxes of about 3 per cent are included. With the tax cut, the U.S. figures would be about the same as in France, Italy, and the United Kingdom.

\section{Contributions for Social Security}

Contributions for social security are much larger in Europe than in the United States. ${ }^{12}$ The expenditures are substantially higher because all the European countries have programs of health insurance, and the benefit levels of the pension and unemployment programs represent larger fractions of normal wage income than in the United States. France and Italy also have extensive programs of family allowances. Table 13 shows the ratios of social security expenditures to national

TABLE 13

EXPENDITURE LEVELS AND SOURCES OF FINANCING OF SOCIAL SECURITY SYSTEMS, 1960

\begin{tabular}{|c|c|c|c|c|c|c|}
\hline & \multirow{2}{*}{$\begin{array}{l}\text { Social Security } \\
\text { Expenditures } \\
\text { as Per Cent of } \\
\text { National Income }\end{array}$} & \multicolumn{5}{|c|}{ Sources of Financing } \\
\hline & & $\begin{array}{l}\text { Insured } \\
\text { Persons }\end{array}$ & Employers & Government & Other & Total \\
\hline & & & & & & \\
\hline $\begin{array}{l}\text { France } \\
\text { Germany } \\
\text { Italy } \\
\text { United Kingdom } \\
\text { United States }\end{array}$ & $\begin{array}{r}16.2 \\
17.0 \\
14.9 \\
9.6 \\
5.3\end{array}$ & $\begin{array}{l}19.2 \\
37.3 \\
15.2 \\
27.0 \\
41.0\end{array}$ & $\begin{array}{l}68.9 \\
40.9 \\
72.4 \\
21.0 \\
45.0\end{array}$ & $\begin{array}{r}7.1 \\
17.9 \\
7.1 \\
51.5 \\
14.0\end{array}$ & $\begin{array}{l}4.8 \\
3.9 \\
5.3 \\
0.5 \\
-\end{array}$ & $\begin{array}{l}100 \\
100 \\
100 \\
100 \\
100\end{array}$ \\
\hline
\end{tabular}

Source: Reld, The Banker, June 1963, p. 413. U. S. flgures computed by the author. For the U.S., public assistance was considered part of social security in order to make the figures more comparable with the European. The part of the expenditures financed by the government represents the public assistance payments.

income, as well as the sources of financing. It can be seen that U.S. expenditures are significantly less than those on the Continent and somewhat less than in Britain. Our method of financing is similar to Germany's. We tax employers less and employees more than do France and Italy. In the United Kingdom a much larger fraction of the financing comes from general revenues.

${ }^{12}$ For a brief survey, see G. L. Reid, "Social Security in Britain and the Six," The Banker, June 1963, pp. 409-416. 
The financing of social security in Germany and the United States is probably more favorable to economic growth than in the other countries. In Italy and France, the high charges on the employer raise the cost of doing business, at least to the extent that the charges are not shifted into higher prices or lower wages. In the United Kingdom, the large share financed out of general revenues is one of the causes for the high level of direct taxation.

Given both the lower level of U.S. expenditures and the financing method, one must conclude that this is one area in which public finance is more favorable to the development of the private sector and to economic growth in the United States than in the other countries.

\section{B. INDIRECT TAXATION}

Taxes other than those classified as direct are known as indirect taxes. Thus, this is a catch-all category of taxes, largely but not wholly levied on transactions; an exception is the property tax in the U.S. I shall classify indirect taxes into two categories: general indirect taxes which are applied across the board, such as value-added taxes, turnover taxes, and purchase taxes of broad scope; and selective indirect taxes, including the excises on individual commodities, customs duties, and stamp and registration taxes. Table 14 summarizes indirect taxes for the central governments.

Unfortunately, a similar table cannot be prepared for all levels of government because rates differ among states and localities. The significance of indirect taxes for local governments can be seen in part from the aggregate figures of Tables 2 and 3 ; while they play a larger role outside the central government than within it in all countries except Italy, the difference is greatest for the United States, where state and local governments collect substantial revenues and rely almost wholly on indirect taxes. The U.S. has particularly heavy local taxation of real property. U.S. property taxes in 1960 were 11 per cent of total government revenue; the figure for local rates in England is about 9 per cent; for the property tax in Germany (Grundsteuer) about 3 per cent; in Italy (imposta sui terreni) about 0.3 per cent; while in France the impot foncier yields 2 to 3 per cent. ${ }^{13}$

\section{General Indirect Taxes}

The value-added tax adopted in France as a substitute for turnover taxation is currently receiving the most attention as a potential source

${ }^{13}$ Les Systemes Fiscaux des Pays Membres de la Communaute Economique Européenne, UNICE, Brussels, 1960. 
EUROPEAN AND U.S. TAX STRUCTURES

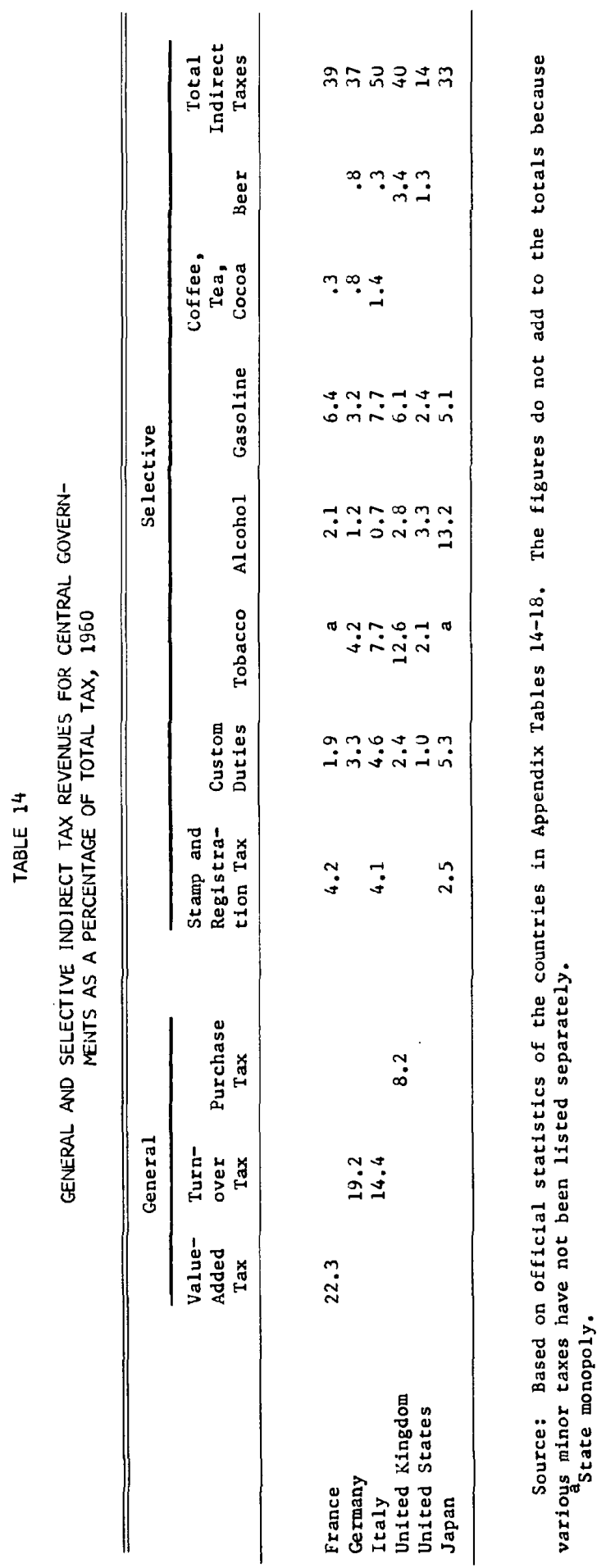


of new revenue. The tax is levied normally at a rate of 20 per cent on the value of total sales including the tax element (25 per cent on luxury articles, 10 per cent on many raw materials, 6 per cent on some foodstuffs, 12 per cent on construction, 5 to 12.5 per cent on various services, and no tax on exports), but credit is given for value-added tax paid on purchased inputs. The tax is levied at the production and wholesale levels. Because of the current interest in this tax, I shall return to it in the closing section of this paper.

Turnover taxes are still important in Germany (at a rate of 4 per cent) and in Italy (3.3 per cent). These are pyramiding sales taxes which are generally acknowledged to have produced excessive vertical integration of industry.

The United Kingdom still applies purchase tax to a broad range of goods, ranging from 5 per cent (e.g., on shoes, furniture, some clothing) to 50 per cent (e.g., on autos, television sets, toiletries). The tax has been used to restrain consumption. Although here classified as a general indirect tax, it could be regarded as a system of selective excise taxes.

\section{Selective Indirect Taxes}

All countries obtain considerable revenue by placing heavy taxes on certain commodities. While tobacco, alcohol, and gasoline are the most commonly chosen items, there is no uniformity of pattern. Stamp and registration taxes are much in use in France and Italy. Tobacco is taxed particularly heavily in the United Kingdom and Italy; in France it is a profitable state monopoly. The United States singles out liquor, while gasoline is taxed very heavily in France, Italy, and the United Kingdom. The United Kingdom is exceptionally hard on beer, Germany and Italy on coffee. No doubt these patterns are the results of national cultures rather than of economic policy.

\section{Tax Policy and Mechanisms of European Growth}

It is impossible to reach meaningful conclusions about the role of tax systems in European growth without having a coherent view of the growth process itself.

In this discussion I proceed in three stages: first, I present a statistical overview of the growth process. Second, I present some qualitative theories which can account for the movement in the aggregate figures. Finally, I draw some very limited conclusions from the analysis about the role of tax policy.

Tax policy and tax systems can affect the growth process in at least 
five ways. First, the automatic response of revenues to economic growth, together with expenditure trends, will help determine the level of aggregate demand. Second, the level of surplus or deficit of the budget ${ }^{14}$ will add or subtract from the supply of saving. Third, the general character of the tax system will influence the total rate of saving and investment. Fourth, specific structural characteristics will influence both total savings and investment and the sectoral distribution of investment. Finally, specific policy measures - that is, acts of policy to change the tax rates or the nature of the taxes themselves-can influence growth, either by design or by accident. ${ }^{15}$ It would be far beyond the scope of this paper to review systematically each of the five tax systems with respect to each of these five matters, and hence I only present some key points.

The role of tax policy must also be evaluated within the perspective of total economic policy. One can ask: of all the measures taken to promote the objective of economic growth, what role was played by tax measures? Elsewhere ${ }^{16}$ I have participated in a detailed comparative study of the use of all instruments of economic policy. For an account of specific measures for each family of instruments (public finance, money and credit, direct controls, changes in the institutional framework, and exchange rates), I refer the reader to that study.

\section{A. Statistical PeRspectives ON GROWTH}

Table 15, taken from a paper by Stanley $\mathrm{H}$. Cohn, ${ }^{17}$ shows the average annual rates of growth of GNP for the five countries studied in this paper, plus the USSR and Japan. The paper decomposes the GNP growth into growth of employment and of productivity, revealing that productivity growth was the more important factor in all cases. The table also presents the ratio of nonresidential investment to GNP. It can be seen that there is a very close association between the rate of advance of productivity and the proportion of total output which each country devotes to nonresidential investment. A high rate of growth

${ }^{14}$ See Andrew H. Gantt, "Central Governments: Cash Deficits and Surpluses," Review of Economics and Statistics, February 1963, pp. 34-46, for a systematic comparison of this matter.

${ }^{15} \mathrm{~A}$ full account of such measures can be found in the NBER-Brookings Conference volume, Tax Policies and Economic Growth in Selected Foreign Countries (in press).

${ }^{16}$ E. Kirschen, J. Benard, H. Besters, F. Blackaby, O. Eckstein, J. Faaland, F. Hartog, L. Morrissens, and E. Tosco, Economic Policy in Our Time, 3 vols., Amsterdam, 1963 and 1964.

${ }^{17}$ Stanley H. Cohn, "Gross National Product in the Soviet Union: Comparative Growth Rates," in Dimensions of Soviet Economic Power, Joint Economic Committee, Washington, 1961, pp. 68-89. 
EUROPEAN AND U.S. TAX STRUCTURES

TABLE 15

GROWTH AND ITS SOURCES, SEVEN COUNTRIES, 1950-60

(per cent)

\begin{tabular}{|c|c|c|c|c|c|}
\hline & \multirow{2}{*}{$\frac{\text { Annual }}{\text { GNP }}$} & \multicolumn{2}{|c|}{ Average Rates of Increase } & \multirow{2}{*}{$\begin{array}{l}\text { Productivity } \\
\text { Advance as a } \\
\text { Share of } \\
\text { Total Growth }\end{array}$} & \multirow{2}{*}{$\begin{array}{c}\text { Nonresidential } \\
\text { Investment as } \\
\text { Proportion of } \\
\text { GNP }\end{array}$} \\
\hline & & Employment & Productivity & & \\
\hline France & 4.3 & 0.4 & 3.9 & 90 & 15.9 \\
\hline Germany & 7.5 & 2.2 & 5.2 & 73 & 19.6 \\
\hline Italy & 5.9 & 1.6 & 4.3 & 78 & 17.2 \\
\hline United Kingdom & 2.6 & 0.6 & 2.0 & 77 & 13.4 \\
\hline Japan & 8.8 & 1.9 & 6.7 & 80 & 23.3 \\
\hline USSR & 6.8 & 1.9 & 4.7 & 74 & 17.7 \\
\hline United States & 3.3 & 1.2 & 2.1 & 66 & 12.9 \\
\hline
\end{tabular}

Source: Cohn in Dimensions of Soviet Economic Power.

over a considerable interval is, with little doubt, always associated with a high rate of nonresidential investment.

The structure of investment also plays a strategic role. Table 16 shows the distribution of investment by type. The United States spends less on equipment and comparable amounts on construction relative to the high-growth countries.

TABLE 16

ELEMENTS OF INVESTMENT AS A PERCENTAGE OF GNP IN SEVEN MAJOR COUNTRIES, 1950-60

(average annual per cent of GNP)

\begin{tabular}{llcc}
\hline \hline & & & Total \\
Cosidential & $\begin{array}{c}\text { Other } \\
\text { Construction }\end{array}$ & $\begin{array}{c}\text { Machinery } \\
\text { and Equipment }\end{array}$ & $\begin{array}{c}\text { Capital } \\
\text { Investment }\end{array}$ \\
\hline
\end{tabular}

\begin{tabular}{|c|c|c|c|c|}
\hline France & 4.8 & 6.2 & 9.6 & 20.6 \\
\hline Germany & 5.8 & 6.4 & 13.2 & 25.4 \\
\hline Italy & 5.6 & 7.1 & 10.1 & 22.9 \\
\hline United Kingdom & 3.3 & 4.7 & 8.7 & 16.8 \\
\hline Japan & 2.4 & 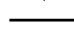 & & 25.6 \\
\hline USSR & 4.0 & 10.2 & 7.5 & 23.9 \\
\hline United States & 4.8 & 6.6 & 6.3 & 17.7 \\
\hline
\end{tabular}

Source: Cohn In Dimensions of Soviet Economic Power.

The distribution of investment among sectors is also revealing (see Table 17). The United States invests relatively more heavily in housing, trade, education, health, military construction, and services, and relatively less in the strategic growth sectors of manufacturing, mining, 


\section{EUROPEAN AND U.S. TAX STRUCTURES}

TABLE 17

SECTORAL DISTRIBUTION OF CAPITAL INVESTMENT IN FIVE LARGE COUNTRIES, 1959

(per cent of total investment)

\begin{tabular}{|c|c|c|c|c|c|c|}
\hline & Agriculture & $\begin{array}{c}\text { Manu- } \\
\text { facturing. } \\
\text { Mining }\end{array}$ & Utilities & $\begin{array}{l}\text { Trans- } \\
\text { porta- } \\
\text { tion } \\
\text { Communi- } \\
\text { cations }\end{array}$ & Housing & Other \\
\hline $\begin{array}{l}\text { Germany } \\
\text { Italy } \\
\text { United Kingdom } \\
\text { USSR } \\
\text { United States }\end{array}$ & $\begin{array}{r}8.3 \\
11.9 \\
4.0 \\
14.1 \\
4.7\end{array}$ & $\begin{array}{l}27.6 \\
22.7 \\
27.3 \\
35.0 \\
16.2\end{array}$ & $\begin{array}{r}5.4 \\
6.4 \\
11.7 \\
4.1 \\
7.1\end{array}$ & $\begin{array}{r}16.1 \\
15.0 \\
13.7 \\
8.5 \\
7.0\end{array}$ & $\begin{array}{l}23.1 \\
28.6 \\
17.8 \\
22.6 \\
30.0\end{array}$ & $\begin{array}{l}19.5 \\
15.4 \\
25.3 \\
15.8 \\
35.0\end{array}$ \\
\hline
\end{tabular}

Source: Cohn in Dimensions of Soviet Economic Power.

utilities, and transportation. Suburban shopping centers do not have the same growth impact, dollar for dollar, as industrial investment, yet these are the outlets in which substantial capital is absorbed in the U.S.

In seeking the causes of the rapid European growth of the postwar period, the most obvious, and perhaps the most important, point is the simple fact that growth was retarded in the prior period. Angus Maddison has prepared comparisons of long-term rates of increase of GNP, which are summarized in Table 18.

It can be seen that the longer-term figures are relatively more uniform.

TABLE 18

RATES OF GROWTH OF GNP, SELECTED INTERVALS

(per cent)

\begin{tabular}{lcccc}
\hline \hline & Germany & Italy & United Kingdom & United States \\
\hline $1870-1913$ & 3.1 & 1.4 & 2.3 & 3.7 \\
$1913-57$ & 2.0 & 2.0 & 1.6 & 2.9 \\
$1913-29$ & 0.5 & 1.8 & 1.3 & 2.8 \\
$1929-38$ & 2.5 & 1.6 & 2.2 & -0.4 \\
$1938-51$ & 0.9 & 1.0 & 1.2 & 5.3 \\
$1951-57$ & 7.5 & 5.4 & 2.5 & 3.0 \\
\hline
\end{tabular}

Source: Angus Maddison, "Economic Growth in Western Europe, 1870-1957," Banca Nazionale del Lavoro Quarterly Review, March 1959, pp. 3-46. U.S. figures from J. Kendrick, Productivity Trends in the United States, Princeton for NBER, 1961, p. 332; figures are for GNP per unit of labor input. 
The recent very high rates for Germany and Italy followed an interval of virtually no growth, while the modest growth in the United States succeeded the preceding rapid expansion. Presumably this catching-up process consisted largely of the introduction of existing technology, the completion of the repair of war damage, and a resumption of the movement of the labor force from agriculture to industry.

But neither crude quantitative relationships between capital and output growth nor the acknowledgment of a catching-up process constitute sufficiently fine theories to permit an analysis of the impact of taxation. I now turn to a more specific view of the changes in economic structure and of the growth process of each of the countries. I believe that these qualitative accounts explain, at least as a first approximation, their happy economic experiences.

\section{B. ANALYSES OF INDIVIDUAL COUNTRIES}

\section{Italy ${ }^{18}$}

The postwar period has seen Italy evolve from a country on the edge of modern industrialism, poor in raw materials and with a market too small to permit efficient production, into a modern economy using the latest technology. At least this is true of the north of Italy, the southern part of the country having been relatively little touched so far.

There has been a considerable growth of certain heavy industries, chemicals, metal manufacture including steel, and automobiles. These industries enjoyed a real rate of growth of 10 to 15 per cent a year. Partly in response to the industrial growth and the resultant growth of incomes, a great construction boom took place and the production of electricity increased at a very high rate. These sectors absorbed a great deal of capital as modern industries were established.

The growth of the industrial sectors was made possible by a very large expansion of exports, a tripling from 1950 to 1959. Italian chemicals, automobiles, and appliances became competitive in markets in Germany and France, and even in the United States. Italian prices in these sectors were stable or falling as unit wage costs remained steady because of the enormous productivity gains. Thus, a circular growth process took place, under which costs were kept low by high productivity gains made possible by a great expansion of exports.

Other factors also had a favorable influence. The formation of the

${ }^{18} \mathrm{~A}$ fuller account of postwar Italian growth can be found in Vera Lutz, Italy, A Study in Economic Development, London, 1962, Chapter 4. 
European Coal and Steel Community helped the steel industry to attain successful development. The income from tourism not only strengthened the balance of payments but added to domestic purchasing power. Wage increases were kept in check by the large influx of labor from rural areas and particularly from the south. Economies of scale were probably realized in other sectors as well.

The process of growth with stable export prices continued until 1962, at which time it appeared to be in some danger. Wholesale prices which had been stable for eleven years started rising, and in the first quarter of 1963 were 5 per cent above the levels of a year earlier. The rate of wage increases became somewhat greater than before, while the rate of increase of industrial production slowed from the 11 per cent which prevailed from 1950 to 1961 to 5 per cent. It remains to be seen whether this is only a pause or a tapering off of the process.

The most important growth measures were taken on the expenditure side: direct public investments, the use of government capital in semipublic enterprises, and the creation of public credit institutions to lend capital to private enterprises. The level of aggregate demand was kept high, rising as fast as production potential.

As for the role of the tax system, the tax treatment of depreciation was liberalized, and, more generally, a relatively light burden of direct taxation helped to facilitate the accumulation of the capital that was necessary for the growth of the strategic sectors. If there had been an acute capital shortage, the growth process would have been slowed and might even have stopped.

The tax system did not create the growth process: it was a permissive factor..$^{19}$ The process itself is attributable to the historical situation, plus the boost that was given to Italian exports by the devaluation of $1949 .{ }^{20}$

\section{France $e^{21}$}

The role of taxation in French growth must be reviewed within the context of total French economic policy. On the one hand, the government permitted a state of general excess demand to continue for most

\footnotetext{
${ }^{19}$ Some specific tax measures were taken to give favorable treatment to investment in the south. Also, during the earlier postwar period when inflation was substantial, some revaluation of assets was allowed for purposes of income taxation.

${ }^{20}$ The tax system was also helpful in some minor ways. The Italian government did not hesitate to use highly selective methods to help exports and discourage imports on occasions.

${ }^{21}$ For an account of French economic policy since World War II, see John Sheahan, Promotion and Control of Industry in Postwar France, Cambridge, Mass., 1963.
} 
of the period, resulting in substantial inflation-more inflation than in most other European countries or the United States. ${ }^{22}$ On the other hand, the government pursued policies of intervention that would not be acceptable in most other capitalist countries, among which were the following:

1. Indicative planning, which during the first plan led to a partly forced rationalization of steel and other basic industries; in later plans it consisted of coordination of investment, plus a raising of sights for business investment plans.

2. Policies which Sheahan has called selective promotion and protection. These include public credit, special depreciation allowances for certain industries such as steel and export producers, favored treatment under the value-added tax, preference on government orders, and favored access to imports of equipment ordinarily restricted. ${ }^{23}$ It also means protection from foreign competition in some cases, most importantly for industrial equipment industries. In recent years, capital has become more readily available from private sources and policies of protection have been circumscribed by the integration with the Common Market, making these policies less important.

3. Selective price controls. Until 1958, the French government maintained a system of price controls for basic industries, including aluminum, steel, automobiles, etc. This policy helped to keep French exports competitive, despite a rather general inflationary process at home. (Some price control measures were resumed in 1963.)

Two other policies deserve mention. At the time that price controls were removed, the franc was devalued, first in a selective way, then across the board in 1958. This devaluation, just at the moment when industrial prices all over the world stabilized, put French exports into a favorable position and has kept them there. France, more than the other European countries, now finds itself with a continued strong balance of payments and good export growth. As Sheahan points out, France learned her lesson in the interwar period of avoiding false, restrictive fiscal and monetary policies and the wrong exchange rate.

The other policy change to which particular interest attaches for this Conference is the adoption of the now famous value-added tax. This tax replaced a pyramided turnover tax, eliminating the previous pressure for excessive vertical integration. By raising the cost of labor, it pro-

${ }^{22}$ But it must be kept in mind that France fought two wars in the 1950's, the war in Indo-China and the war in Algeria, which necessitated diversion of substantial resources to military purposes.

${ }^{23}$ Sheahan, Promotion and Control, pp. 27-28. 
vided an incentive for the introduction of labor-saving machinery. The adoption of the value-added tax also opened up the possibility of its selective use: the tax has been remitted on export industries and has been deliberately used to influence industry investment choices.

Can the success of French postwar growth be attributed to the policies of intervention? It must be acknowledged that France shares the favorable historical situation with the other continental countries, and there was some catching up to do. Consumer incomes passed through the levels at which the demand for durables becomes particularly great, stimulating, in turn, the production of all heavy industry, leading to large productivity gains from economies of scale and the introduction of modern technology. The expansion of heavy industry, including the associated investment in electricity and other basic utilities, makes a high rate of capital formation necessary and possible.

Nevertheless, it would be false to argue that the policy of intervention had no effect. Sheahan's book makes it clear that French intervention is more than just exhortation; the government has the power and the desire to change private decisions about investment, about prices, and about plant location. One could argue that French growth would have been just as high without intervention. But it would have been a different growth of the economic structure; the rationalization of the steel industry, the investment and product innovation in the automobile industry made by the state-owned Renault Company, and numerous other large and small changes were the results of government action and would not have occurred otherwise. Thus, it is a synthetic question to ask what the growth of the French economy would have been in the absence of government intervention. Sheahan concludes that postwar French intervention represented a change in government policy. In his brilliant conclusion he writes:

In the interwar period, French governments sided with the forces of conservation against change, impeding an initially low level of private initiative, whether the particular governments were conservative in conventional political terminology or whether they were not. The basis of the transformation in postwar France was that important agencies of government, as distinct from that mythical entity, "the government," reversed alliances. They reached into the economy to side with particular business forces favorable to progress. In the first years they provided direct initiative through new managements in some of the previously weak or particularly crucial basic industries. They stimulated private initiative through plans which could, if stripped of their obsession with concentration, raise 
the level of performance without destroying competition in any society. They did not determine the growth rate, they merely improved it.

It is as much a mistake in France as in the United States to consider issues of alternative market organization primarily in terms of a conflict between government intervention and private business choice. The true opposition is between the complex of forces favorable to initiative and progress, which may come from either government or private enterprise, and the obstacles to progress which may equally well come from either side. No nation is or ever will be free of the latter, because the impediments to economic progress are rooted in the search for reduction of uncertainty and in the impossibility of considering one's own and others' interests on perfectly equal terms.

Apart from the specific interventions by fiscal methods and the change-over from a turnover to a value-added tax, the general character of the French tax system cannot be said to have played an important role in the growth process. Fiscal policy as a whole was inflationary as the government found it impossible to finance the two wars out of taxes. The burden of personal income taxes was lighter than in the United Kingdom or the United States, but personal saving did not constitute an important source of capital. As for the level of business taxation, it cannot be said to be light, though tax relief has been used selectively to favor investment by certain industries. The French experience is interesting as a study of selective state intervention for growth. But all in all, I do not believe that it sheds much light on the desirability of different combinations of direct and indirect taxes.

\section{Germany (Federal Republic)}

While German growth must also be viewed primarily in terms of the configuration of historical circumstance, the role of the tax system in fostering growth can be seen more clearly. The German labor force has had the potential of high productivity for a number of decades. Both mechanical skills and the attitude toward work have been favorable. The population has also been eager to accumulate capital both personally and as managers of business. It was only the Great Depression, the war, and the temporary disorganization of the economy at the end of the war which kept German output from developing to its full potential. After the currency reform restored order to the economy, and after the Marshall Plan aid gave a massive infusion of capital to help start a self-generating growth process, the German economy moved ahead quickly and steadily. The influx of East German refugees made for an 
abundant supply of labor until the end of the 1950's and impressed upon the government and private decision-makers the imperative necessity of economic expansion.

General fiscal policy was not particularly restrictive. On the whole, demand pressed on the supply of output through most of the period. Thus, expansion was largely a production problem, and there was no question that the extra output made possible by the high rate of capital formation would find a ready market.

The pattern of domestic demand also reinforced the growth process. There was a great demand for consumer durables and for housing, which led to major expansion in the metals and other heavy industries.

Perhaps most important was the rise in German exports at the fantastic rate of 15 per cent a year from 1950 to 1961. This export success can be attributed to several factors: First, to some extent it represented the recapture of markets in the Balkans, Turkey, and the Middle East, which traditionally had been German markets. Second, the economic integration of a rapidly growing Western Europe, first through trade liberalization and then through the formation of the Common Market, made for a big increase in exports within Europe. Third, German export prices behaved substantially better than American or British export prices, and permitted Germany to gain in other markets and in the U.S. Fourth, German business takes exports seriously, sends some of its best personnel abroad, and works hard at pleasing foreign customers. Fifth, the government helped promote exports by assuring the availability of export credit and by giving a rebate on the turnover tax.

The key element in the German export story is perhaps the stability of export prices, even in the face of the great increase in sales and a progressively tighter labor market. This cost stability is primarily due to the tremendous increase of productivity which was associated with the expansion of output, partly because of economies of scale and partly because of the introduction of new technology. Thus, even though wages rose by relatively large amounts, unit labor costs did not increase, even while Germany's main competitors were suffering from rising costs of exports.

The tax system was the main instrument of economic policy for growth. Before 1950, selective devices were used. To foster personal saving, income put into savings accounts for a minimum period was exempted from income taxation. Depreciation allowances were liberalized, and in order to draw capital into the reconstruction of some heavy industries, special depreciation allowances were instituted for 
them, and moral suasion was used to make certain industries provide capital to the basic sectors. After 1950, the emphasis changed from selective devices toward general rate reduction. The burden of direct taxation was made substantially lighter, both on business and on households, sufficiently light that the enormous needs for capital for economic expansion could be met out of private sources. Further, the development of the private capital market was fostered through the preferential tax treatment accorded to distributed profits as opposed to retained earnings.

\section{United Kingdom}

Many of the arguments offered to explain the high growth in the continental countries should also be applicable to the United Kingdom. Per capita real income levels were about the same, consumption of durable goods was heavy, and there also was catching up to do because of the war and the depression. What went wrong?

I think it is more difficult to explain the British failure to grow rapidly than to account for continental successes. One can point to weakness of entrepreneurship; but that argument was made about France not so long ago. Protected markets sheltered inefficient firms, but are British tariffs higher than on the continent? Perhaps the attitudes of unions toward technological change were worse and there may have been other intangible factors. Major selective measures of tax policy, including initial allowances and investment allowances, were taken to stimulate capital formation, yet they clearly did not suffice to assure successful growth.

Among the more objective factors, two can be singled out. First, British export experience was rather poor despite considerable government exhortation. British export prices rose under the impetus of domestic inflation and a stubborn retention of a fixed exchange rate. With export markets difficult to maintain under deteriorating price conditions and with domestic demand kept high most of the time, business returns on marketing effort were greater at home than abroad. Further, the frequent balance-of-payment crises led to sudden tightening of fiscal and monetary policies which interfered with the growth process. ${ }^{24}$

The other strategic phenomenon is the low savings rate. The United Kingdom saved and invested less than the continental countries, partly reflecting a particularly progressive direct-tax system. The low savings

${ }^{24}$ For a discussion of the effect of balance of payment movements on investment, see Ragnar Nurkse, "The Relationship between Home Investment and External Balance in the Light of British Experience, 1945 to 1955," Review of Economics and Statistics, May 1956, pp. 121-154. 
may well have kept the British economy from growing at a higher rate. Shortage of capital was a significant phenomenon, particularly during the balance-of-payment crises. It would be a mistake to attribute the entire slow growth to this one factor, however. The tax treatment of depreciation was liberal, and generous investment allowances were instituted. The incremental capital-output ratio in the United Kingdom was high, so that each dollar of investment produced relatively little extra output.

While these comments are meant to suggest some of the possible reasons for the relatively slower growth of the United Kingdom, I can only conclude that there remains an element of mystery. As Table 19

TABLE 19

\begin{tabular}{lr} 
INCREMENTAL CAPITAL-OUTPUT RATIOS, & $1950-60^{\mathrm{a}}$ \\
\hline \hline France & 6.2 \\
Germany & 6.3 \\
Italy & 6.6 \\
United Kingdom & 9.4 \\
Japan & 5.1 \\
USSR & 5.6 \\
United States & 10.4 \\
\hline
\end{tabular}

Source: Cohn in Dimensions of Soviet Economic Power.

${ }^{a}$ Cumulative capital investment in constant prices divided by increase in output per employee.

$b_{1953-60 .}$

shows, the countries with high investment rates also had the most favorable incremental capital-output ratios. In a static, classical world, one would expect the diminishing returns to additional investment to produce a negative relationship between the rate of investment and the incremental capital-output ratios. Thus, either there are economies of scale to additional investment for industrial economies at the present stage of European development, or the capital-output ratio was much less favorable in the U.K. for other reasons.

\section{Conclusions}

\section{A. EUROPEAN TAX SYSTEMS}

Europe is no tax paradise, not even for the rich or for corporations. The total level of taxation in relation to GNP is greater than in the United States. Direct taxation as a whole is of the same general magnitude 
in Germany and the United Kingdom (and other northern countries such as the Netherlands, Sweden, and Norway not studied in this paper) as in the United States. It is lower in France and Italy, with their different tax traditions. The extent of nominal progression is lower on the continent than here, but if the proposed tax program is enacted, our tax system will no longer differ so greatly even in this respect. The direct taxation of business is fairly uniform among the countries, with the heaviest burden probably in Germany.

\section{B. TAXES AND EUROPEAN GROWTH: RELEVANCE OF THE FINDINGS FOR THE UNITED STATES}

European experience can be considered relevant in two senses. First, it can be viewed as a shopping list of individual policy measures. Since Europe grew more rapidly than the U.S., all European experience has the happy validation of success. Liberalized depreciation and other investment incentives first caught the American eye. French planning and the value-added tax are the current rage. Devaluation has not achieved a similar popularity, though it certainly had much to do with European growth.

The other sense in which European experience can be considered relevant is for an analysis of the over-all economic strategy that was pursued, particularly the budget policies which achieved both full employment and a high investment rate. Could this strategy succeed for the United States as well?

\section{A Value-Added Tax for the United States?}

In the United States, the value-added tax would presumably not be used as a substitute for other indirect taxes, but rather as a partial or complete replacement for the corporation income tax. Such a change would have seven important effects:

1. Corporations with high profits would be taxed less, unsuccessful corporations would be taxed more. From the point of view of an efficient allocation of investment, such a tax change would be desirable, since it would lead to a greater internal generation of capital in profitable industries where returns are high, at the same time tending to withdraw capital from the declining sectors. This argument does not apply to profits which result from monopoly power.

While desirable from an efficiency point of view, the heavier taxation of unsuccessful companies would lead to major problems of adjustment. As long as the economy as a whole is not in a state of full employment, a 
deliberate worsening of the situation of the declining industries cannot be undertaken lightly.

2. The tax would lead to the substitution of capital for labor, i.e., it would hasten automation. This is because a value-added tax would fall both on labor and capital inputs, while the corporation income tax only falls on the return to capital. Capital deepening may be desirable in the long run, but in the present situation of general unemployment the government should hardly seek to increase technological displacement of workers.

3. The tax could be imposed upon a broader range of business organizations than corporations, bringing cooperatives, mutual financial institutions, unincorporated business, and possibly even state enterprises into the tax base. This broadening of the base would be desirable, and if a new tax provides the opportunity for this major reform it would be a strong argument for the tax. It is a political question whether the unincorporated businesses could succeed in gaining exemption from the tax in Congress.

4. The value-added tax would have lower marginal rates to yield the same amount of revenue. This would remove some of the tax-caused distortions in decision-making in such areas as expense accounts.

5. A switch to the value-added tax would raise the amount of business saving, particularly if it could be passed on in higher prices to a greater extent than the corporation income tax. Under full employment, a higher savings rate would be desirable for the sake of economic growth. Whether a regearing of the tax system toward more saving under present conditions is desirable is a broader issue (see below).

6. The value-added tax would be a weaker automatic stabilizer than the corporation income tax, since profits are more sensitive to cyclical changes than value added. The loss in automatic stabilization would be substantial.

7. The tax would encourage exports, provided that exported goods are free of tax. ${ }^{25}$

\section{A High Rate of Saving Strategy?}

It would theoretically be possible for the United States to duplicate the European experiences of the 1950's by gearing its tax system to permit a high saving and investment rate for economic growth. We could change our tax system so as to produce more saving and then run

\footnotetext{
${ }^{25}$ See the paper by Musgrave and Richman in this volume for an analysis of the several effects through which exports are influenced.
} 
budget deficits of sufficient magnitude to have total spending equal to total potential output. The deficits required for this strategy would be larger than those under the present tax system. If we did not enlarge the deficits to offset the saving, the restructuring of the tax system would merely produce a decline in total demand, lower utilization rates in industry, lower before-tax profits, and create more unemployment. ${ }^{26}$

Unlike the European countries, the United States gives no evidence that capital is particularly scarce. The capital markets have been relatively easy for over three years. Corporations are in a relatively liquid position. The capital-output ratio is substantially greater than in the rapid-growth European countries. In this connection, the role of residential construction must be particularly considered. It has been our general experience that residential construction can absorb great quantities of capital when it is available on cheap terms. While better housing no doubt has some effect on worker productivity, it cannot be said to give the same stimulus to growth as industrial capital formation, which can embody new technology and raise the marginal productivity of labor more directly. If a successful strategy of a higher saving rate were to result primarily in a greater volume of residential construction, one could not expect as favorable a result for economic growth as Europe obtained from its high saving rates.

What about the future? The proposed tax program, if combined with favorable developments in the private economy, should return us to full employment by 1966 . In that happy event, the issue of raising the saving rate can more properly be raised, and proposals for alternative methods of taxation, such as the value-added tax, should then be given a full hearing.

Let me conclude on the question around which this Conference is organized. Does the United States have too much direct taxation? This question has to be answered in the light of the statistical evidence and the tax proposals now before Congress. The widely used and startling figures of Table 1, which show the U.S. tax system to be wholly out of line with that of every other country, are derived from a statistical fallacy. Any meaningful set of comparisons shows the differences in tax systems among countries to be much smaller, with the German system in particular resembling that of the United States.

More important, the tax changes already enacted-depreciation re-

${ }^{26}$ For a further discussion of these issues, see my paper "The Tax Structure and the Functioning of the Economy," Proceedings of the National Tax Association for 1962, pp. 243-245. 
form and the investment credit-are largely ${ }^{27}$ reductions of direct taxes. The current proposals consist wholly of very large reductions in direct taxes; they also remove the most objectionable feature of our direct-tax system, the extreme nominal progression of the income tax. It seems to me that we have done enough to redress the balance between direct and indirect taxes in the United States, at least for the moment.

${ }^{27}$ Excise taxes on transportation have also been cut. 


\title{
Appendix: Notes on European Tax Systems
}

\author{
VITO TANZI \\ HARVARD UNIVERSITY
}

THIS appendix presents some of the structural characteristics of the major taxes of the tax systems of the countries discussed in the Eckstein paper. It is presented here as background and to provide some supporting detail to the tables and discussion of the paper.

Unless otherwise indicated, the tax systems are described as they were during 1961.

\section{Personal Income Taxes and Other Taxes on Persons}

FRANCE

France has a progressive personal income tax on total income and a complementary tax (taxe complementaire) on income from profits, land, and buildings.

Personal Income Tax (Impôt sur le Revenue des Personnes Physiques)

1. The rates of this tax for a single person without dependents are as follows $(5 N F=\$ 1)$ :

$\begin{array}{cc}\text { Income }(N F) & \text { Rates }(\text { per cent) } \\ 0-2,300 & 5 \\ 2,300-3,750 & 15 \\ 3,750-6,500 & 20 \\ 6,500-9,750 & 25 \\ 9,750-16,250 & 35 \\ 16,250-32,000 & 45 \\ 32,000-64,000 & 55 \\ 64,000 \text { and over } & 65\end{array}$

While the maximum marginal rate is 65 per cent, the marginal effective rate is limited to 55 per cent. When taxable income per unit exceeds $8,000 \mathrm{NF}$, a 5 per cent surcharge is added to the tax. Income below $70 N F$ is not taxed.

2. France provides extensive income-splitting for families. Income is split among family "units," with each unit taxed separately on its share 
of the total income. The determination of the number of units is not straightforward, however, since there is not a one-to-one relationship between the number of persons constituting the family and the number of units allowed for taxation purposes. Some typical cases are shown below:

Number of Units

Single with no dependents

Married without children

Single or divorced with two dependents

Married with two dependent children

Each additional child

0.5

3. Wages and salaries are reduced by 10 per cent for "occupational expenses," with a further reduction of 20 per cent on the remaining amount before it is added to other income to compute taxable income. Furthermore, once the tax has been calculated it is reduced by 5 per cent of the salaries and wages included in the computation of taxable income; this deduction must be viewed in combination with the payroll tax of 5 per cent paid by business, which is in a sense a substitute.

4. The tax on dividends is withheld at the source at the rate of 24 per cent. The taxpayer includes the dividends in his income and deducts the tax withheld at the source from the total tax.

5. Capital gains are not usually taxed in the case of individuals except when they arise in connection with a business.

\section{Complementary Tax (Taxe Complémentaire)}

This is usually charged only on incomes from profits, land, and buildings and not on incomes from wages and salaries.

1. In 1960 and 1961 the rate was 8 per cent; in 1963 it was 6 per cent.

2. Exemptions are 4,400 NF for profits from a profession or a handicraft trade and 3,000 NF for profits from other sources (industrial, agricultural, etc.).

\section{GERMANY}

\section{Personal Income Tax (Einkommensteuer)}

This is a progressive tax levied on total income. Taxable income includes the imputed rental value of owner-occupied property. The revenues from this tax are shared between the federal government ( 35 per cent) and the Länder (65 per cent). It provides more than 50 per cent of the fiscal revenues of the Länder. 
1. The effective rates at various levels of income for single persons are as follows $(4 \mathrm{DM}=\$ 1)$ :

$\begin{array}{crc}\text { Taxable Income }(D M) & \text { Tax }(D M) & \begin{array}{c}\text { Effective Rate } \\ \text { (per cent) }\end{array} \\ 1,710 & 6 & .04 \\ 3,000 & 264 & 8.80 \\ 5,000 & 660 & 13.20 \\ 10,000 & 1,816 & 18.16 \\ 20,000 & 4,938 & 24.69 \\ 50,000 & 17,238 & 34.48 \\ 100,000 & 41,815 & 41.82 \\ 200,000 & 94,719 & 47.36 \\ 500,000 & 253,719 & 50.74 \\ 1,000,000 & 518,719 & 51.87\end{array}$

The tax on married persons can be calculated by deducting the allowances for children from taxable income, ascertaining the tax on half this amount and multiplying by two.

The methods by which these rates are obtained, together with the various deductions and exemptions, are described below.

For taxable incomes from $1,680 \mathrm{DM}$ to $8,009 \mathrm{DM}$, the tax rate is 20 per cent. This rate is given by the formula $0.2[Y-(900+780)]$, where $Y$ is the taxable income rounded to the closest thousand.

For taxable incomes between $8,010 \mathrm{DM}$ and $23,999 \mathrm{DM}$, the tax is given by the formula $0.2\left[8,000-(900+780)+272 Y+2.9 Y^{2}\right]$, where $Y$ is the part of the taxable income rounded to the closest thousand above 8,000 DM.

For taxable incomes between $24,000 \mathrm{DM}$ and $110,039 \mathrm{DM}$, the formula is $6358+382 Y+1.572 Y^{2}-0.006 Y^{3}$, where $Y$ is the figure of taxable income which exceeds $24,000 \mathrm{DM}$, rounded to the nearest thousand.

The marginal rate for any part of income exceeding $110,040 \mathrm{DM}$ is 53 per cent.

2. The law allows a basic deduction of $564 \mathrm{DM}$ from wages and salaries in order to cover the expenses connected with employment. When the expenses are itemized and exceed $564 \mathrm{DM}$, a further deduction is given. When the income originates from capital rather than from labor, the deduction is $150 \mathrm{DM}$ for single and married persons. 
Subject to certain specified limits, interest on loans, annuities, premiums for life, sickness, accident and unemployment insurance, medical expenses, charitable contributions, certain local taxes, and taxes on capital may be deducted from taxable income. Persons may use as an alternative a standard deduction of $636 \mathrm{DM}$ for wage and salary earners and $200 \mathrm{DM}$ for others.

The personal exemption from income is $1680 \mathrm{DM}$ each for the taxpayer and his wife and $1200 \mathrm{DM}, 1680 \mathrm{DM}$, and $1800 \mathrm{DM}$, respectively, for one, two, and three or more children. Taxpayers over 50 years of age receive an extra exemption of $840 \mathrm{DM}$ or $1200 \mathrm{DM}$ under certain conditions. Taxpayers over 70 get an additional exemption of $600 \mathrm{DM}$.

In addition to personal exemptions and deductions, relief is provided families by income-splitting.

3. Capital gains are taxed as a general rule only if they are derived from professional trades; however, capital gains from the sale of movable assets are taxed if the holding period is less than six months. Capital gains on real estate are taxed if the holding period is less than two years. Capital gains associated with the sale of stock are taxed only if the person holds more than 25 per cent of the total stock outstanding and the sale exceeds 1 per cent of the nominal capital of the company.

4. Individuals, like corporations, are subject to a net worth tax (Vermögensteuer) of .75 to 1 per cent on their net wealth (see Section III below for details).

ITALY

\section{Personal Income Tax: Schedular Taxes}

Italy is the only country among the four under consideration with a schedular tax system, in which the income of every individual is classified according to certain schedules. Each schedule has its own rates, with substantial differences among them. The schedular taxes are as follows:

1. The tax on undeveloped land (imposta sui terreni) is a tax imposed at a rate of 10 per cent on the income value of land as shown on a general land register. Surcharges are imposed by provincial and municipal governments. These may amount to 20 per cent of the income value of the land.

2. The tax on buildings (imposta sui fabbricati) is a tax on the rent from buildings at a rate of 5 per cent. When the owner occupies the property, an imputed rent is used as the basis of taxation. The rent is 


\section{EUROPEAN TAX SYSTEMS}

reduced by one-fourth before the tax is applied, in recognition of the depreciation of the building. However, there are also provincial and municipal government rates, which may bring the combined figure to as high as 32.5 per cent.

3. The rate of the tax on income from agriculture (imposta sui redditi agrari) is 23 per cent.

4. The schedule for the tax on income from capital, capital and labor, and professions and employment (imposta di ricchezza mobile) subdivides income into four categories and each is taxed according to its appropriate rate. These categories with the respective rates are shown in Table 1.

TABLE 1

RATES OF TAX ON INCOME FROM CAPITAL, CAPITAL AND LABOR, AND PROFESSIONS AND EMPLOYMENT, ITALY

(per cent)

\begin{tabular}{ccccc}
\hline \multicolumn{1}{c}{$\begin{array}{c}\text { Income } \\
\text { Categories }\end{array}$} & $0-240,000 \mathrm{~L}$ & $\begin{array}{c}240,000- \\
960,000 \mathrm{~L}\end{array}$ & $\begin{array}{c}960,000- \\
4,000,000 \mathrm{~L}\end{array}$ & $\begin{array}{c}4,000,000 \mathrm{~L} \\
\text { and 0ver }\end{array}$ \\
\hline $\begin{array}{l}\text { A. Income from capital } \\
\quad \text { (Interest etc.) }\end{array}$ & 23 & 23 & 23 & 23 \\
B. Income from cap1tal \\
$\begin{array}{l}\text { and labor combined } \\
\text { (business profits) }\end{array}$ & 0 & & & 20 \\
$\mathrm{C}_{1}$. Professional income & 0 & 9 & 8 & 8 \\
$\mathrm{C}_{2}$. Employment income & 0 & 4 & 8 & 8 \\
\hline
\end{tabular}

Note: $\$ 1 \otimes 625 \mathrm{~L}$.

\section{Personal Income Tax: Global Tax on Income}

(Imposta Complementare Progressiva sul Reddito Complessivo)

Total income, the sum of the incomes on the several schedules, is taxed by the global tax, which alone gives some progressivity to the system. The global tax rate ranges from 2 to 50 per cent on incomes over 500,000,000 lire (see Table 2). Since incomes of this magnitude are very rare in Italy, the very high rates are of negligible importance. The total revenues from the global tax for the year 1959-60 were only 73 billion lire, or about 2.4 per cent of total fiscal revenues. The scale for the global tax on income is obtained from the formula: $Y=0.023015 \sqrt{x}$ $-0.0000472 x+0.00874$, where $Y$ is the tax and $x$ is the income in million lire.

There is a personal exemption of $240,000 \mathrm{~L}$ and exemptions of 50,000 L each for the spouse and each dependent child. Incomes of less than 720,000 L before exemptions are exempted from this tax. 
EUROPEAN TAX SYSTEMS

TABLE 2

RATES OF GLOBAL TAX ON INCOME; ITALY

\begin{tabular}{cccc}
\hline $\begin{array}{l}\text { Taxable Income } \\
\text { (thousand 11re) }\end{array}$ & $\begin{array}{c}\text { Marginal Rate } \\
\text { (per cent) }\end{array}$ & $\begin{array}{c}\text { Taxable Income } \\
\text { (thousand 11re) }\end{array}$ & $\begin{array}{c}\text { Marginal Rate } \\
\text { (per cent) }\end{array}$ \\
\hline 240 & 2 & 20,000 & 11.08 \\
500 & 2.50 & 30,000 & 13.34 \\
1,000 & 3.17 & 40,000 & 15.25 \\
2,000 & 4.12 & 50,000 & 16.92 \\
3,000 & 4.85 & 70,000 & 19.81 \\
4,000 & 5.46 & 90,000 & 22.29 \\
5,000 & 6.0 & 100,000 & 23.43 \\
6,000 & 6.49 & 150,000 & 28.37 \\
7,000 & 6.93 & 200,000 & 32.49 \\
8,000 & 7.35 & 250,000 & 36.10 \\
9,000 & 7.74 & 300,000 & 39.34 \\
10,000 & 8.11 & 400,000 & 45.04 \\
& & 500,000 & 50.0 \\
\hline
\end{tabular}


$Y=0.023025 \sqrt{X}-0.0000472 X+0.00874$,

where $Y$ is the tax and $X$ is the income in million lire. This formula when solved gives the scale in the above table.
}

For the purpose of this tax, the income of the wife (if any) is added to that of the husband. Most of the other taxes on income (schedular taxes) can be deducted in computing the taxable income for the purposes of imposta complementare.

The combined burden of the schedular tax and the progressive global tax is illustrated by Table 3, for an employed person, married and with two children.

Capital gains are not taxed.

\section{Family Tax (Imposta di Famiglia)}

This is a local community tax on the global income of the whole family, with rates varying from community to community. The rate structure is usually progressive, the maximum rate which can be imposed being 14.4 per cent, the minimum 2 per cent. The tax provides about 17 per cent of the total revenues of the communities.

\section{UNITED KINGDOM}

The United Kingdom income tax structure includes an income tax and a surtax.

1. The income tax is charged, in principle, at a flat rate (the standard rate) of 38.75 per cent. Progressivity, however, is provided by a number of personal deductions and other relief devices. 
TABLE 3

TOTAL TAX FOR MARRIED PERSON WITH TWO CHILDREN, ITALY (thousand 11re)

\begin{tabular}{ccccc}
\hline \hline & $\begin{array}{c}\text { Schedular Tax } \\
\text { (incl. 10\% } \\
\text { additions) }\end{array}$ & $\begin{array}{c}\text { Progressive } \\
\text { Surtax (incl. } \\
10 \% \text { additions) }\end{array}$ & $\begin{array}{c}\text { Total Tax } \\
\text { Annual Salary } \\
\text { Lire }\end{array}$ & Per Cent \\
\hline & & & & \\
875 & 39 & 12 & 51 & 5.8 \\
1,750 & 112 & 47 & 159 & 9.1 \\
2,625 & 189 & 97 & 286 & 10.9 \\
3,500 & 266 & 155 & 421 & 12.0 \\
4,375 & 343 & 224 & 567 & 13.0 \\
5,250 & 420 & 296 & 716 & 13.6 \\
7,000 & 574 & 448 & 1,022 & 14.6 \\
8,750 & 728 & 639 & 1,367 & 15.6 \\
17,500 & 1,498 & 1,794 & 3,292 & 18.8 \\
26,250 & 2,268 & 3,257 & 5,525 & 21.0 \\
43,750 & 3,808 & 6,900 & 10,708 & 24.5 \\
\hline
\end{tabular}

Source: E. B. Nortcliffe, Common Market Fiscal Systems, London, 1960 , p. 6.

The income tax is levied under the following five different schedules according to the nature and source of income:

Schedule A: Income from land, buildings etc., including, until 1963, the imputed rent of owner-occupied houses.

Schedule B: Income from forest land.

Schedule C: Interest from government securities.

Schedule D: Profits of trades, businesses, professions, interest on loans, income from abroad, etc.

Schedule E: Income from employment.

The method of assessment of the income depends on the schedule in which it falls, but the rates are uniform on all schedules.

Taxable income of individuals over $£ 2000$ is subject to the surtax. The following shows the rate of surtax at selected levels of income:

$\begin{array}{ccrc}\text { Net Income (£) } & \begin{array}{c}\text { Surtax } \\ \text { (per cent) }\end{array} & \text { Set Income }(£) & \begin{array}{c}\text { Surtax } \\ (\text { per cent })\end{array} \\ 0-2,000 & 0 & 5,000-6,000 & 27.5 \\ 2,000-2,500 & 10.0 & 6,000-8,000 & 32.5 \\ 2,500-3,000 & 12.5 & 8,000-10,000 & 37.5 \\ 3,000-4,000 & 17.5 & 10,000-12,000 & 42.5 \\ 4,000-5,000 & 22.5 & 12,000-15,000 & 47.5 \\ & & \text { Over } 15,000 & 50.0\end{array}$


2. The United Kingdom does not allow income-splitting for married couples. The incomes of husband and wife are combined and taxed at the regular rates. Limited relief is provided by the fact that a larger personal exemption is given to married persons than to single persons, $£ 240$ and $£ 140$, respectively. For children below 11 years of age, the allowance is $£ 100$; for those between 11 and $16, £ 125$; for students over 16 , it is $£ 150$.

Besides these allowances, the first $£ 360$ of taxable income is taxed at lower rates: the first $£ 60$ is taxed at 8.75 per cent; the next $£ 150$ at 21.25 per cent; and the next $£ 150$ at 31.25 per cent (as of 1962). The

TABLE 4

INCOME TAX AND SURTAX ON SPECIMEN INCOMES OF SINGLE PERSONS AND MARRIEO COUPLES WITHOUT CHILOREN, UINITED KINGDOM

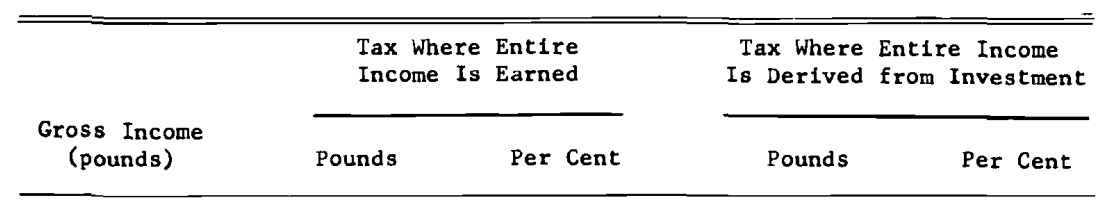

SINGLE PERSON

\begin{tabular}{|c|c|c|c|c|}
\hline 500 & 49 & 9.80 & 84 & 16.80 \\
\hline 1,000 & 192 & 19.20 & 277 & 27.70 \\
\hline 2,000 & 493 & 24.65 & 665 & 33.25 \\
\hline 3,000 & 794 & 26.47 & 1,165 & 38.83 \\
\hline 5,000 & 1,440 & 28.80 & 2,340 & 46.80 \\
\hline 10,000 & 4,098 & 40.98 & 5,952 & 59.52 \\
\hline 100,000 & 83,227 & 83.23 & 85,602 & 85.60 \\
\hline
\end{tabular}

MARRIED COUPLE WITHUUT CHILDREN

$\begin{array}{rrrrr}500 & 24 & 4.80 & 52 & 10.40 \\ 1,000 & 152 & 15.20 & 239 & 23.90 \\ 2,000 & 454 & 22.70 & 626 & 31.30 \\ 3,000 & 756 & 25.20 & 1,114 & 37.13 \\ 5,000 & 1,401 & 28.02 & 2,279 & 45.58 \\ 10,000 & 4,027 & 40.27 & 5,876 & 58.76 \\ 100,000 & 83,138 & 83.14 & 85,514 & 85.51\end{array}$

Source: Income Taxation in the U.K., U.S. Department of Commerce, Economic Reports.

Note: $\quad b l=\$ 2.80$. 
rates were changed in 1963 as follows: the first $£ 100$ at 20 per cent, the next $£ 200$ at 30 per cent. There are further allowances for earned income: two-ninths of the gross income earned, up to $£ 4,005$, and oneninth of the income between $£ 4,005$ and $£ 9,945$ may be deducted from taxable income. Thus, there is a maximum possible allowance of $£ 1,550$ on an earned income of $£ 9,995$ or more. Earned income includes investment income of persons whose total income does not exceed $£ 300$ and persons over 65 years of age with incomes under $£ 800$.

The burden of the income tax and surtax when all the allowances permitted are taken into consideration is shown in Tables 4 and 5 .

Capital gains are not taxed in the United Kingdom.

TABLE 5

INCOME TAX ON SPECIMEIN INCOMES OF MARRIED COUPLES WITH CHILDREN, UNITED KINGDOM

\begin{tabular}{|c|c|c|c|c|c|c|}
\hline \multirow{2}{*}{$\begin{array}{l}\text { Income } \\
\text { (pounds) }\end{array}$} & \multicolumn{2}{|c|}{$\begin{array}{l}\text { One Child } \\
\text { Not Over } 11\end{array}$} & \multicolumn{2}{|c|}{$\begin{array}{l}\text { Two Children } \\
\text { Not Over } 11\end{array}$} & \multicolumn{2}{|c|}{$\begin{array}{l}\text { Three Children } \\
\text { Not Over } 11\end{array}$} \\
\hline & Pounds & Per Cent & Pounds & Per Cent & Pounds & Per Cent \\
\hline 500 & 4 & .80 & - & - & -- & -- \\
\hline 1,000 & 114 & 11.40 & 77 & 7.7 & 46 & 4.60 \\
\hline 2,000 & 416 & 20.80 & 377 & 18.85 & 338 & 16.90 \\
\hline 3,000 & 717 & 23.90 & 678 & 22.60 & 639 & 21.30 \\
\hline 5,000 & 1,363 & 27.26 & 1,324 & 26.48 & 1,286 & 25.72 \\
\hline 10,000 & 3,956 & 39.56 & 3,885 & 38.85 & 3,813 & 38.13 \\
\hline 100,000 & 83,050 & 83.05 & 82,961 & 82.96 & 82,872 & 82.87 \\
\hline
\end{tabular}
Reports.

Source: Income Taxation in the U.K., U.S. Department of Commerce, Economic

\section{Corporate Taxes and Other Taxes on Business}

Not all the countries under consideration tax the income of corporations separately. There is a separate tax in France, Germany, the United Kingdom, and the United States, but not in Italy. This section will describe briefly the legal structure of this tax in each of the countries.

FRANCE

\section{Corporate Income Tax (Impôt sur les Sociétés)}

All incorporated enterprises in France are subject to this tax.

1. The rate of the corporate income tax is a flat 50 per cent on the total profits of the corporation. In general, no reduction is granted on 
the part of the profits that is distributed; the corporation is, furthermore, required to withhold a tax of 24 per cent of the dividends (impôt unique, retenue a la source). However, dividends paid on new shares issued for purposes approved by the government are deductible. Furthermore, under certain conditions, dividends received by a parent company are exempted from the 24 per cent deduction at the source. This withheld tax on dividends is credited by the shareholder against the progressive income tax which is charged on his total income including the dividends received.

2. In the evaluation of its total profits, the corporation is required to include any gains which arise from the sale of assets. If the capital gains are reinvested within three years, they are not taxed. Capital gains realized by the transfer or cessation of the business are normally taxed if such transfer or cessation has taken place less than five years from the day of formation of the business; they are taxed at reduced rates if the cessation or transfer has occurred after five years. Since 1962, capital gains on land held less than seven years have been taxed at 25 per cent.

3. The basis for depreciation is either the declining-balance method (permitted since January 1, 1960) or the straight-line method. After January 1, 1965, the declining-balance method will be compulsory. The basis for the computation is the original cost.

4. Losses may be carried forward for five years as an offset against profits.

5. There are no investment allowances in France.

6. No tax-free reserves for the replacement of the capital assets are allowed.

7. Current expenditures incurred on scientific or technical research and development are deductible from income in the year in which they are incurred.

\section{Other Taxes on Business}

1. Businesses are subject to a payroll tax (versement forfaitaire) on the salaries and wages paid to the employees in a year. The rates for this tax are: 5 per cent on total payroll of each employee not exceeding $30,000 \mathrm{NF}$; 10 per cent on the excess over $30,000 \mathrm{NF}$ up to $60,000 \mathrm{NF}$; and 16 per cent on any excess over $60,000 \mathrm{NF}$.

2. The business licence tax (contribution des patentes) is a local tax which any person or legal entity involved in any business transactions 


\section{EUROPEAN TAX SYSTEMS}

must bear. The rate is flat and varies from establishment to establishment according to production, number of employees, etc.

\section{GERMANY}

\section{Corporate Income Tax (Körperschaftsteuer)}

This is a tax on the profits of corporations and other legal entities operated for profit. The revenues from this tax are shared between the federal government ( 35 per cent) and the Länder (65 per cent). The tax provides about 6 per cent of the revenues of the federal government and about 20 per cent of those of the Länder.

1. The basic rate is 51 per cent on retained profits for incorporated companies and 49 per cent for unincorporated associations. The portion of profits of incorporated firms which is distributed to the stockholders is taxed at the preferential rate of 15 per cent.

Dividends cannot be deducted as expenses for the purposes of the corporation tax.

The arrangement by which dividends receive preferential treatment helps the firms which rely on the capital market for funds, but may create serious difficulties for some small firms. The law has tried to meet these difficulties by giving these firms the opportunity to choose a progressive scale of taxation which reduces the difference in tax burden between distributed and undistributed profits. In order to qualify, a firm must have at least 76 per cent of its share capital in the hands of private persons, it must have its shares in registered form, and its net worth must not exceed 5 million DM. For these firms the maximum rate of 49 per cent is reached at 50,000 DM, while the rate on the distributed profits is 26.5 per cent.

The law includes many provisions which seek to prevent tax evasion taking the form of distributing profits from one company to a dependent one. The receiving companies are required to distribute the profits received.

Profits are computed by valuing the net worth of the companies at the beginning and the end of the fiscal period. Inventories are to be valued either at the initial value or at the market value if the latter is lower.

2. All capital gains from any source are normally taxed as profits.

3. The basis for depreciation is the historical cost of the asset. As a rule, the straight-line method is used, but in the case of movable business 
assets the declining-balance method is also permitted, with the limitation that the depreciation cannot be more than twice that calculated by the straight-line method nor can it exceed 20 per cent. Sometimes the Teilwert basis may be used, which is defined as "that part of the total value of the business as a going concern which is attributable to the asset." For example, if an asset costs 1 million DM and the accumulated depreciation is $500,000 \mathrm{DM}$, and thus the book value is 500,000 $\mathrm{DM}$, but the imputed real value of the asset is only $400,000 \mathrm{DM}$, then the imputed value (the Teilwert) is substituted for the book value and the difference between the book value $(500,000 \mathrm{DM})$ and the imputed value $(400,000 \mathrm{DM})$ is taken as additional depreciation.

There are no standard rules regulating the period of depreciation, allowances for which must be negotiated in each case. In some special cases accelerated depreciation is permitted.

4. Losses may be carried forward for five years as an offset against profits.

5. There are no investment allowances.

6. Two kinds of tax-free reserves are permitted: The first is for increase of prices (Rücklage für Preissteigerung), for cases in which the replacement value of an asset has increased by more than 10 per cent over the year. Profit in excess of a return of 10 per cent attributable to the price increase may be currently excluded from taxable income but must be included within six years. The second is for high replacement cost (Rücklage für Ersatzbeschaffung).

7. Expenditure on fundamental research (Grundlagenforschung) is included in deductible expenses. The same is true for product development (Neuentwicklung).

\section{Other Taxes on Business}

1. The tax on industry and trade (Gewerbesteuer) is a very important tax levied on behalf of the localities on all business enterprises, whether incorporated or not. Three elements constitute the base for this tax: profits of the enterprises, net worth, and payrolls.

The tax law provides basictrates to which each municipality applies its own coefficient (Hebesätze) to get its effective rates. The basic rates are as follows: 5 per cent on profits, 0.2 per cent on net worth, and 0.2 per cent on payroll. The effective (actual) rates are substantially different from the basic rates and vary from locality to locality. The average effective rates however are: 13.55 per cent on profits, 0.54 per cent on net worth, and 2 per cent on payroll. This tax provides about 70 per 
cent of the total revenues of the communities. It is deductible from income for purposes of income or corporate tax.

2. Companies as well as individuals are subject to the net worth tax (Vermögensteuer), which applies to the total assets of an enterprise. The revenues go to the provincial governments (Länder). The tax provides, together with the tax on individuals, about 6 per cent of the total revenue of the Länder.

The rate is 1 per cent on the total value of the net assets of the companies. This tax is not deductible from income for corporate tax.

\section{ITALY}

Italy, unlike the other countries under consideration, has a schedular tax system with different tax rates for each schedule. For both individuals and corporations, when the income arises out of business it is taxed according to category $\mathrm{B}$ (imposte sui reditti di ricchezza mobile), the category for income from capital and labor combined.

The rate on income under category $B$ is 18 per cent for an income up to 4 million lire and 20 per cent on the excess. Local taxes increase the first rate to about 27.85 per cent and the second to 31.23 per cent. There is no exemption for companies.

Nowhere does the Italian law state precisely what constitutes income or how it is to be defined. In general, income (or profit) is assumed to be the increase in net wealth accruing to the taxpayer (individual or company) as a result of the application of capital and labor.

Capital gains are always taxed as income.

Inventories are valued at either their original cost or market value. Since 1951 the LIFo method has been permitted.

The basis for depreciation is the straight-line method, but other methods are also recognized. The tax authorities have set down for guidance the maximum rates allowable on various types of assets, for certain activities. These rates need not be followed, however. The basis of valuation for depreciation purposes is the original cost of the asset.

The maximum authorized rates (in per cent) are listed below:

Rates

Buildings

Textile, paper, printing, rubber, and plastics industries 3

Mining, metallurgical, and mechanical engineering industries

Chemical industry 
Plant and machinery

General rates

Rates for special machinery used in:

Chemical, metallurgical, and engineering industries $\quad 8-15$

Mining

Office machines and furniture $\quad 10$

Motor vehicles

Accelerated depreciation is allowed for assets requiring intensive use and for new industries, for which the depreciation period is reduced by two-fifths.

3. Since 1956 losses can be carried forward for a period of five years.

4. There are no investment allowances.

5. Usually no tax-free reserves are permitted. On the other hand, due to the depreciation of the lire, some revaluation of assets has been allowed.

6. Expenditure for research may be deducted in full in the year in which it takes place, or a normal depreciation procedure may be used:

\section{Other Taxes on Business}

1. The company tax (imposta sulle societa) is not to be confused with a corporation tax in the American sense. This is both a property tax and a profits tax. The tax is made up of two parts: 15 per cent on the portion of profit which exceeds 6 per cent of net worth, and 0.75 per cent on the net worth itself. Thus the tax combines a capital and profit element.

2. The tax on bonds and debentures (imposte sulle obbligazioni) appearing on the balance sheet of a company is at the rate of 0.5 per cent.

\section{UNITED KINGDOM}

Companies are subject to the same income tax which is levied on individuals and to a profits tax in addition.

1. The income tax is levied at the flat rate of 38.75 per cent, the same as the "standard" rate on the income of individuals. However, while individuals are permitted certain deductions, none are allowed for corporations.

The profits tax is charged in addition to the income tax at the rate of 15 per cent of profits. Thus the combined rate is 53.75 per cent. The profits tax, however, does not apply to profits under $£ 2000$. For profits 
less than $£ 12,000$, the assessment is reduced by one-fifth of the balance of $£ 12,000$.

In the case of a corporation, the income tax (38.75 per cent) does not apply to both company profits and the dividends distributed from the profits. The tax paid by the company on the part of profits distributed as dividends is withheld from the dividend payments, and the stockholder receives a credit for this amount against his liability.

No statutory rule is provided for the valuation of inventories; cost or market price, whichever is lower, is the usual practice. FIFO is the standard procedure.

2. Capital gains are not usually taxed, and thus the United Kingdom differs from the countries considered above.

3. The basis for depreciation for buildings is the original cost of construction; for mineral deposits overseas, the price that the first U.K. purchaser paid; for all others, the cost to the actual owner.

The method used for depreciation varies with the type of asset. A straight-line method is required for industrial buildings and capital expenditure on scientific research and patents. A straight-line or decliningbalance method is used for equipment, machinery, etc.

The rates of depreciation are as follows: 2 per cent per year for industrial buildings; three-fifths in the first year and one-tenth in the remaining years for capital expenditure on scientific research. If the taxpayer follows standard established rates, however, once he has calculated the annual depreciation charges, he is allowed to increase these charges by multiplying them by $\frac{5}{4}$.

4. Losses may be carried forward against profits without time limit, and in the event of cessation of business, they may be carried backward for three years.

5. The United Kingdom grants several forms of investment allowances. In the case of capital expenditure typical rates are: 10 per cent for industrial buildings plus an initial allowance of 5 per cent; 20 per cent for new machinery plus an initial allowance of 10 per cent; 20 per cent for capital expenditure for mining, works, etc., plus a 20 per cent initial allowance.

The investment allowance is in the nature of a bonus (depreciation above 100 per cent) while the initial allowance reduces the subsequent depreciation allowances.

6. Tax-free reserves are not generally allowed.

7. Current costs for research are deductible. Capital expenditure on scientific research receives preferential treatment. 


\section{Personal Capital Taxes}

FRANCE, ITALY, AND THE UNITED KINGDOM

There are no special taxes on capital or wealth.

\section{GERMANY}

Germany has a net worth tax (Vermögensteuer) on both individuals and corporations. The basis for the imposition of the tax is the net value of all wealth that the individual or the corporation has on German $\mathrm{s}$ il. The rate is either 1 per cent or .75 per cent. The revenues are granted to the provinces (Länder). The revenues from this tax for 1960 were 1100 million DM, or 1.93 per cent of total federal and state taxes for that year.

\section{Succession and Gift Taxes}

FRANCE

In France, gifts and successions are subject to the same levy. The only succession and gift duty now in force is calculated with reference to the value received by each beneficiary and according to his or her degree of relationship to the deceased or the donor. The rates for property passing in direct line or between husband and wife are as follows (in per cent):

$\begin{array}{lr}\text { First } 50,000 \mathrm{NF} & 5 \\ \text { Next } 50,000 \mathrm{NF} & 10 \\ \text { Excess over } 100,000 \mathrm{NF} & 15\end{array}$

The rates for property passing in other cases are (in per cent):

$\begin{array}{ll}\text { Between brothers and sisters } & 40 \\ \text { Between uncles, aunts, nephews, } & \\ \text { nieces, etc., to third degree } & 50 \\ \text { Others } & 60\end{array}$

The duty thus calculated is increased by a surcharge when the beneficiary is more than 30 years of age and childless. The surcharges are 15 per cent for married or widowed beneficiaries and 25 per cent for single or divorced beneficiaries. There are significant exemptions: for a direct-line descendant or husband or wife, the first 100,000 NF of the gift or inheritance is tax-exempt. 


\section{GERMANY}

Succession duties are payable in Germany on property passing to each beneficiary. The duty is calculated and charged separately on the bequest to each beneficiary. The rates vary from 2 to 60 per cent according to the size of the estate and the degree of relationship. The exemption varies from $30,000 \mathrm{DM}$, for surviving spouse or children, to $1,000 \mathrm{DM}$ for strangers.

\section{ITALY}

There are two death duties in Italy. The first is levied according to a sliding scale on the total amount of the estate of the deceased. The second is charged on the net amount received by each beneficiary on a sliding scale which varies with the degree of relationship between the deceased and the beneficiary (see Table 6).

Gifts are subject to the same duties. There are some basic exceptions.

TABLE 6

TYPICAL RATES OF DEATH DUTIES, ITALY

(per cent)

\begin{tabular}{|c|c|c|c|c|c|c|}
\hline $\begin{array}{c}\text { Amount } \\
\text { of Estate } \\
\text { (milion lire) }\end{array}$ & $\begin{array}{l}\text { Tax on } \\
\text { Total } \\
\text { Estate }\end{array}$ & $\begin{array}{l}\text { Direct } \\
\text { Line }\end{array}$ & $\begin{array}{l}\text { Wife } \\
\text { or } \\
\text { Husband }\end{array}$ & $\begin{array}{l}\text { Brother } \\
\text { or } \\
\text { Sister }\end{array}$ & $\begin{array}{l}\text { Uncle, Aunt, } \\
\text { Niece, or Nephew }\end{array}$ & Others \\
\hline $0-1$ & 1 & 1 & 2 & 3 & 5 & 15 \\
\hline $10-15$ & 9 & 9 & 12 & 22 & 25 & 46 \\
\hline $50-75$ & 20 & 20 & 25 & 41 & 51 & 70 \\
\hline Above 500 & 35 & 35 & 40 & 60 & 70 & 80 \\
\hline
\end{tabular}

\section{UNITED KINGDOM}

Estate duties are payable on the value of all property, real or personal, which is transferred to other persons on the death of the owner. The rates of taxation are shown in Table 7.

Business assets and land subjected to estate tax twice within a fiveyear period are taxed the second time on a reduced scale.

\section{Social Security}

The social security programs of the Western European countries are by far the most extensive in the world. It is for this reason that the contributions to social security are such a large proportion of personal income. 
EUROPEAN TAX SYSTEMS

TABLE 7

RATES OF ESTATE DUTIES, UNITED KINGDOM

\begin{tabular}{cccc}
\hline \hline $\begin{array}{c}\text { Value of } \\
\text { Estate } \\
\text { (pounds) }\end{array}$ & $\begin{array}{c}\text { Rate } \\
\text { (per cent) }\end{array}$ & $\begin{array}{c}\text { Value of } \\
\text { Estate } \\
\text { (pounds) }\end{array}$ & $\begin{array}{c}\text { Rate } \\
\text { (per cent) }\end{array}$ \\
\hline Up to: & & Up to: & \\
& & & \\
3,000 & 0 & 45,000 & 28 \\
4,000 & 1 & 50,000 & 31 \\
5,000 & 2 & 60,000 & 35 \\
7,500 & 3 & 75,000 & 40 \\
10,000 & 4 & 100,000 & 45 \\
12,000 & 6 & 150,000 & 50 \\
15,000 & 8 & 200,000 & 55 \\
17,500 & 10 & 300,000 & 60 \\
20,000 & 12 & 500,000 & 65 \\
25,000 & 15 & 750,000 & 70 \\
30,000 & 18 & $1,000,000$ & 75 \\
35,000 & 21 & Over $1,000,000$ & 80 \\
40,000 & 24 & & \\
\hline
\end{tabular}

Source: Taxation in Western Europe, Federation of British Industries, London, 1961, p. 175.

Relevant information on social security for the countries considered is summarized in Table 8.

\section{Indirect Taxes}

\section{FRANCE}

Taxe sur le Chiffre d'Affaires

This tax is made up of three separate taxes, of which the first is by far the most important. These are:

1. The value-added tax (taxe sur la valeur ajoutée). Unlike the turnover tax of Germany and Italy, this tax is charged only on the value added in a given enterprise. Value added is the difference between the selling price of the product and the cost of the various inputs used in producing the product which had already been subject to tax. Because this tax is charged only on the value added in the enterprise, it is not cumulative and thus does not pyramid. The tax is actually calculated by applying the tax rate to gross taxable sales and then deducting from this figure all taxes paid on purchases during the period. Exports are exempt, and all taxes paid on exported goods at earlier stages in the production and distribution channels are refunded.

The normal rate is 20 per cent on value including tax. Lower rates (10 and 6 per cent) are applied to certain goods regarded as necessities, 
EUROPEAN TAX SYSTEMS

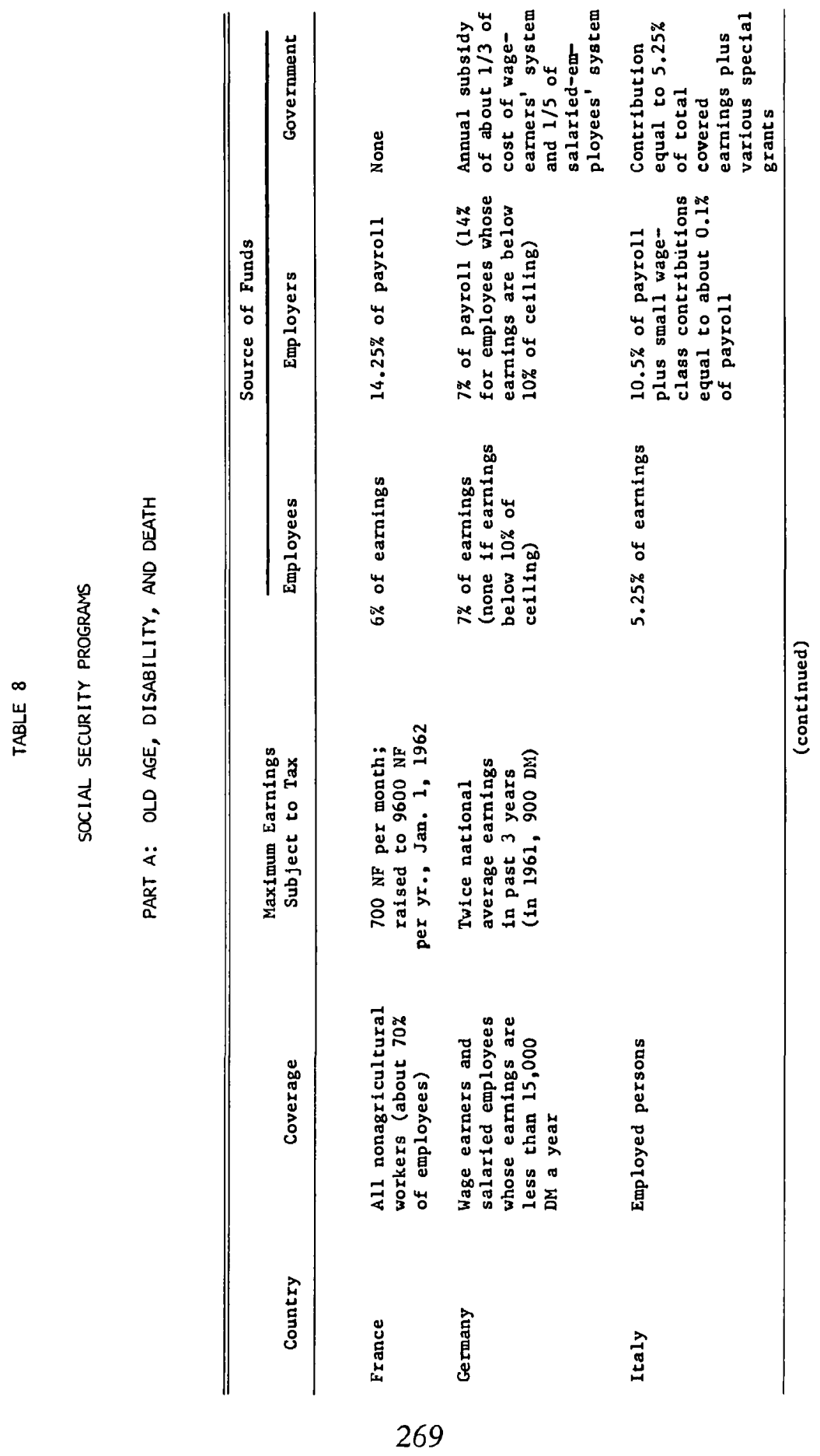


EUROPEAN TAX SYSTEMS

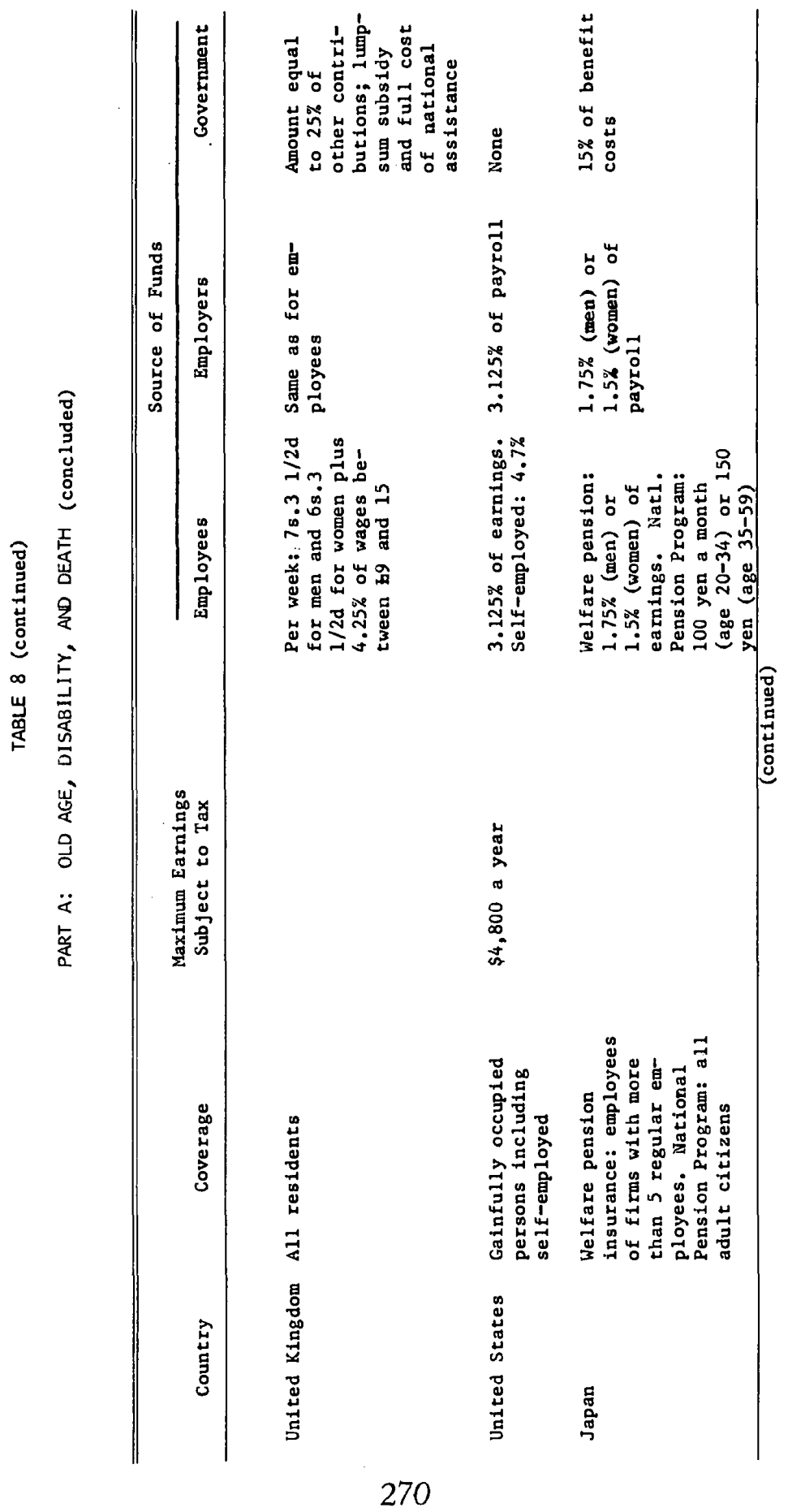


EUROPEAN TAX SYSTEMS

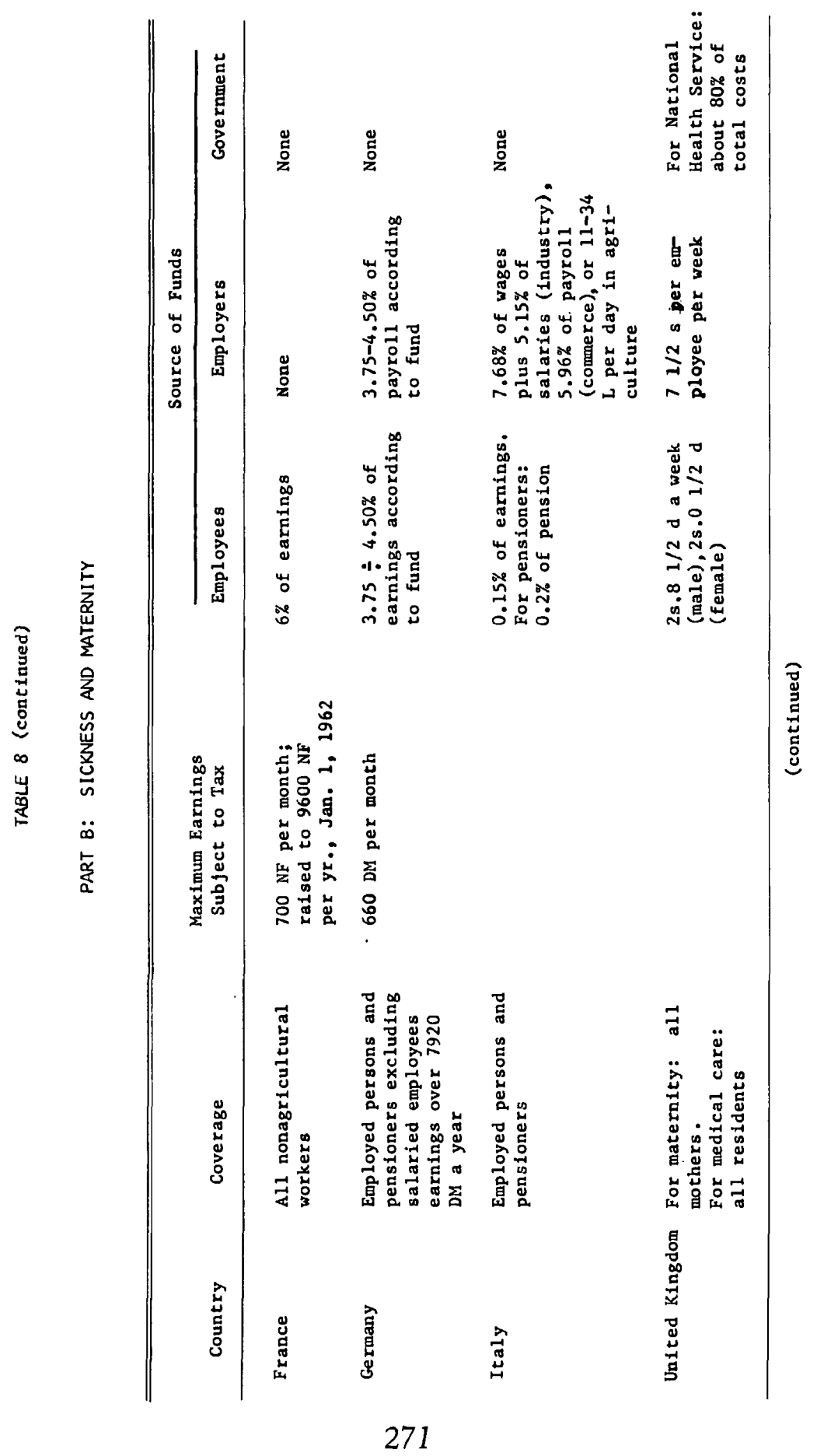




\section{EUROPEAN TAX SYSTEMS}




EUROPEAN TAX SYSTEMS

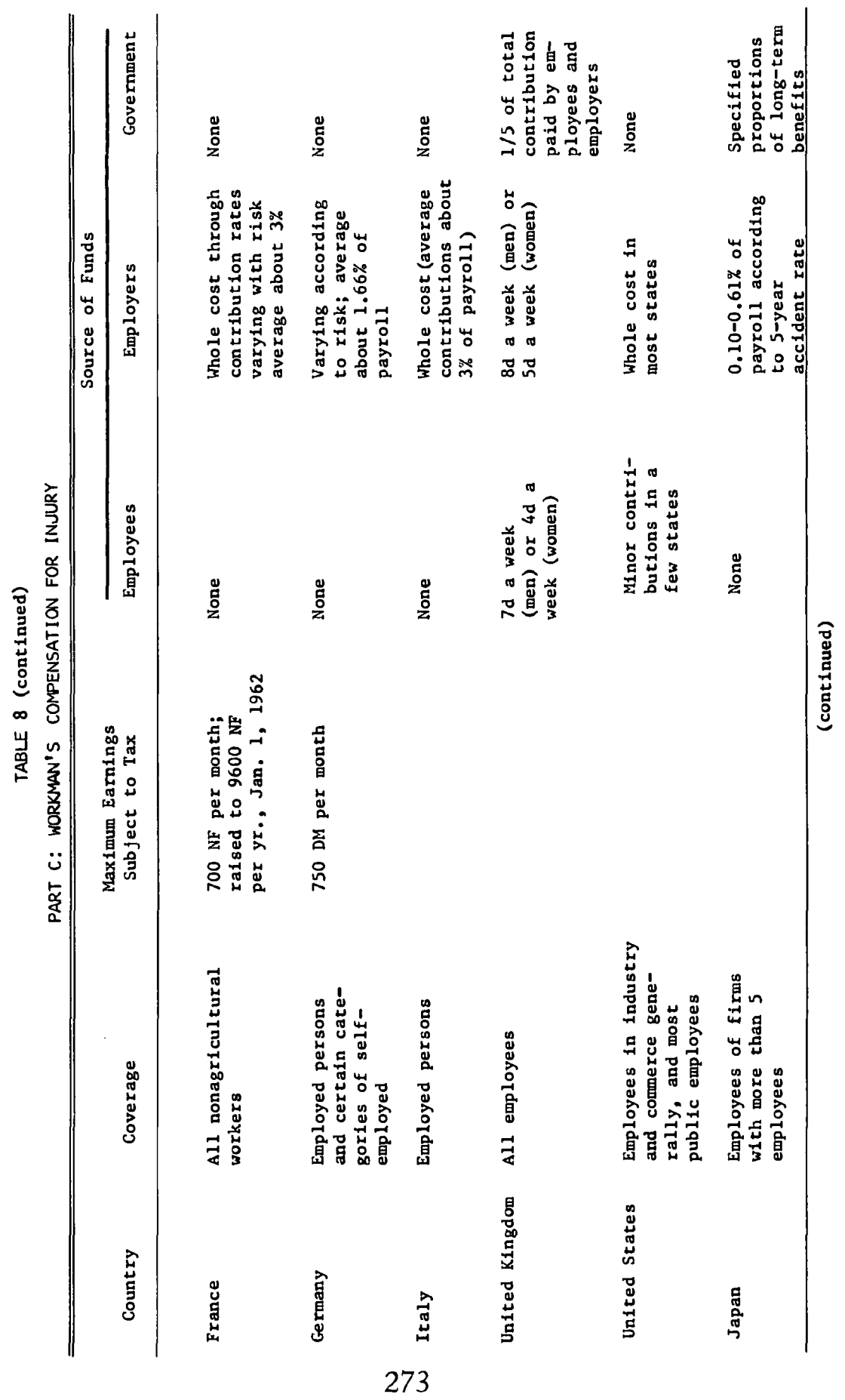


EUROPEAN TAX SYSTEMS

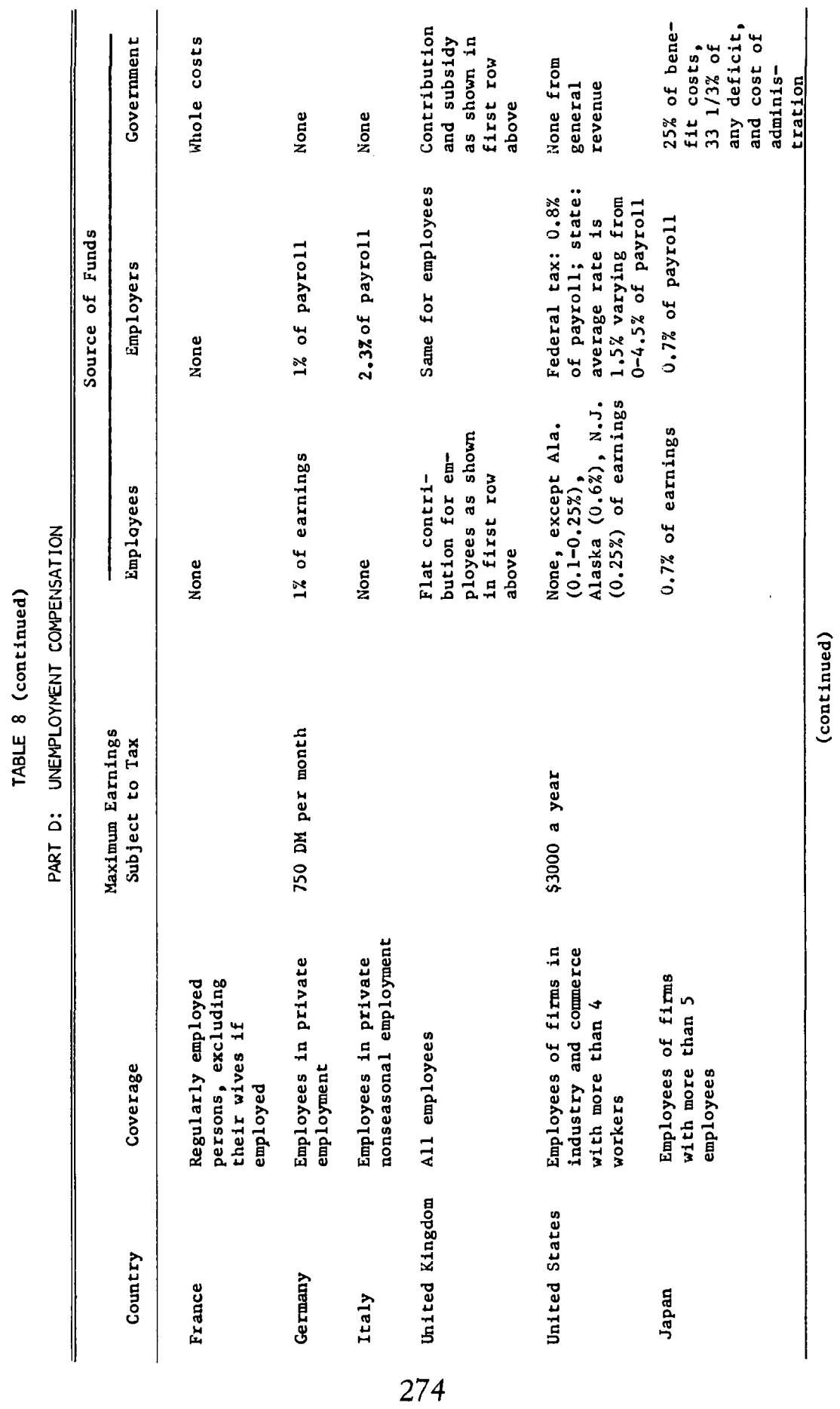




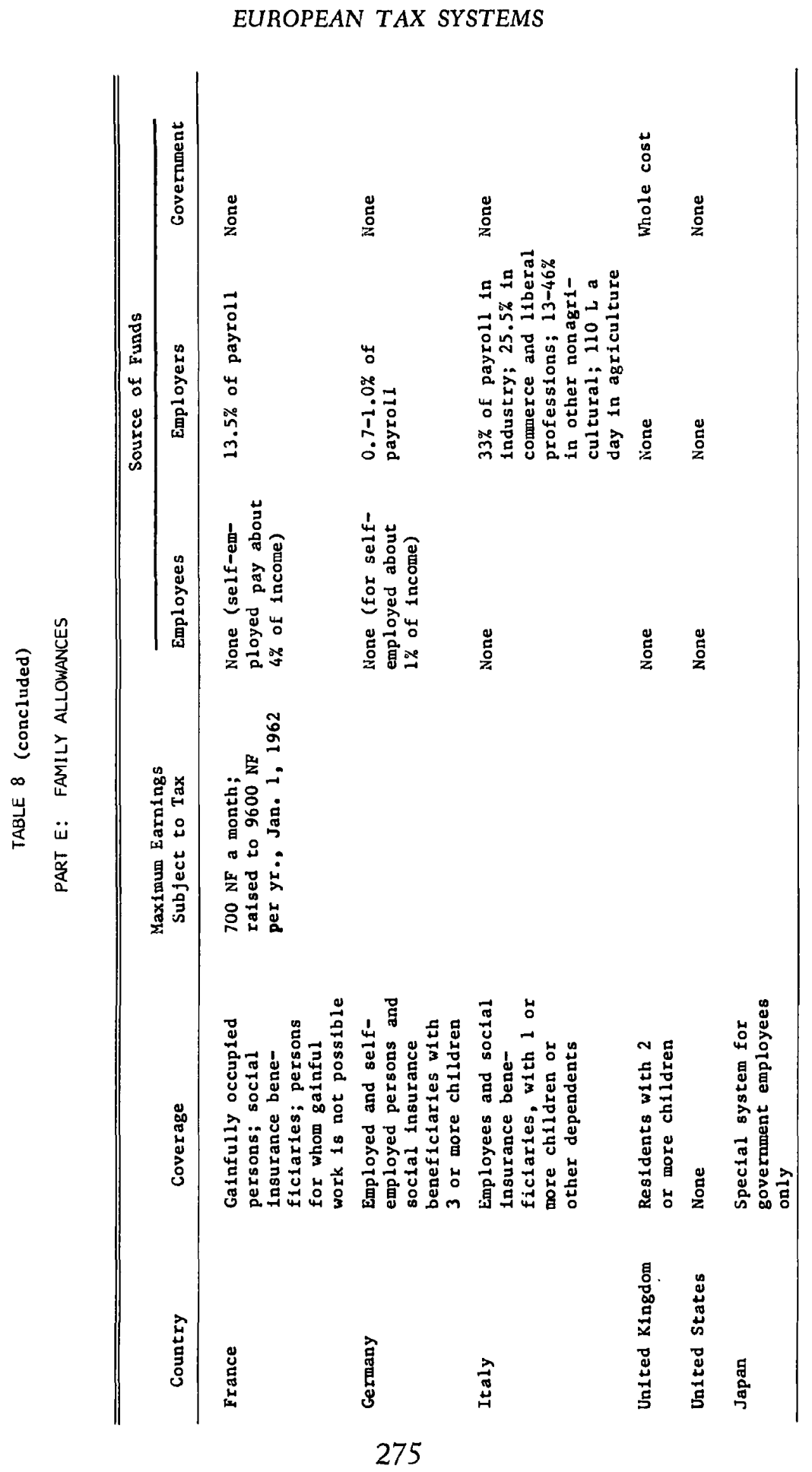


and higher rates (23 and 25 per cent) to certain goods regarded as luxuries.

The tax is a major element in the French tax system, yielding about 25 per cent of the total tax revenue.

2. Tax on services (taxe sur les prestations de services). The performing of certain services is subject to a separate services tax, in lieu of the value-added tax. The tax is paid by those who perform the services, but they normally bill it separately on the invoice to the customer.

The normal rate is 8.5 per cent, with a 12 per cent rate on certain categories. This tax yields about 3 per cent of the total tax revenues.

3. Local tax (taxe locale). This is typically a tax on the retail sales of commodities, levied for the benefit of local government units. The tax is also applied to certain services not taxed by the tax on services (e.g., brokerage, etc.).

The normal rate is 2.75 per cent but can be increased to 8.50 per cent for certain commodities. The revenues from this tax are distributed as follows: from 60 to 70 per cent goes to the municipalities, and 15 per cent to the départements. The remainder goes to the Fonds National de Compensation. This tax yields about 34 per cent of the total revenues of the municipalities.

\section{GERMANY}

\section{Turnover Tax (Umsatzsteuer)}

The German turnover tax is, unlike the French one, of a cascade type; that is, it is a multiple-stage tax. Each transaction is taxed on the basis of gross receipts rather than value added.

Exports are exempted from this tax, as are wholesale sales of certain foodstuffs and raw materials.

The basic rate is 4 per cent. For food products, the rate is 3 per cent; for products of the forestry industry, 1.5 per cent; for sales by wholesalers, 1 per cent.

This is an extremely important tax in the fiscal system of Germany, providing about 45 per cent of the fiscal revenues of the federal government and about 25 per cent of the total fiscal revenues of all levels of government.

\section{ITALY}

Turnover Tax (Imposta Generale sull'Entrata, I.G.E.)

The Italian turnover tax, like the German, is of the cascade type, charged on each transfer down to, but not including, the retail level. The tax is not levied on exports. 


\section{EUROPEAN TAX SYSTEMS}

The general rate is 3.3 per cent, with special rates for certain products ranging from 0.60 to 9.90 per cent. The revenues from this tax average about 23 per cent of the total revenues.

UNITED KINGDOM

\section{Purchase Tax}

This is a sales tax limited to specified categories of consumer goods. It is collected on the last wholesale transaction.

The rates vary from 5 per cent on clothing and furniture to 50 per cent on certain durable consumer goods and luxury goods.

INDIRECT TAXES ON SELECTED ITEMS

A table in Eckstein's paper has provided the percentages of total revenues which derive from each major class of indirect taxes. The purpose of this appendix, in this respect, is to provide some information on the rates at which these items are taxed. The relevant information has been summarized in Table 9, which follows this section. The figures have been converted to dollars and cents to make comparison easier. The table is limited to the main items but the taxes reported account for about 90 per cent of the total revenue from indirect taxation.

\section{Country Tax Systems}

The actual revenues from the various taxes for a given year are shown in Tables 10-14. 
EUROPEAN TAX SYSTEMS

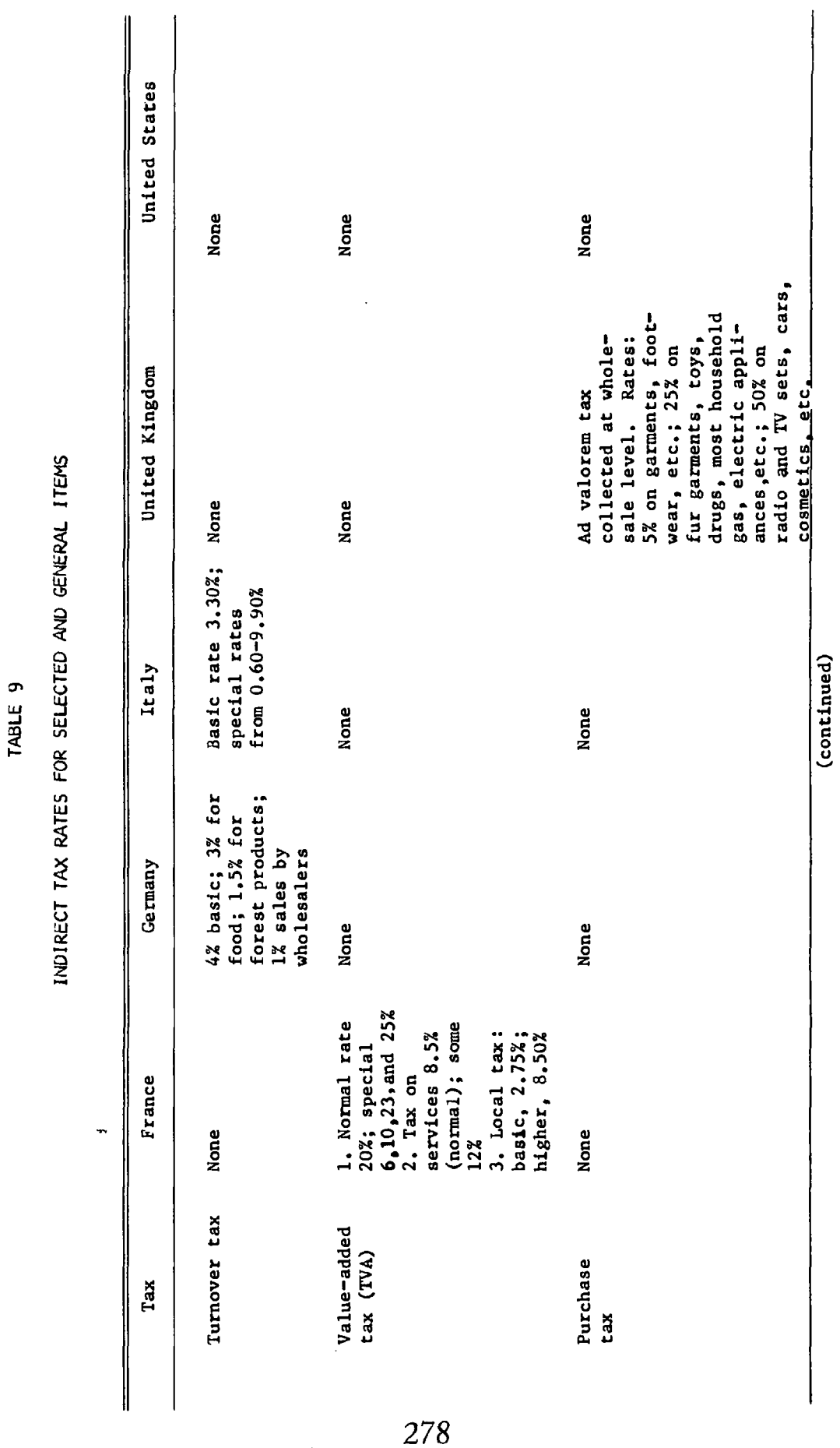


EUROPEAN TAX SYSTEMS

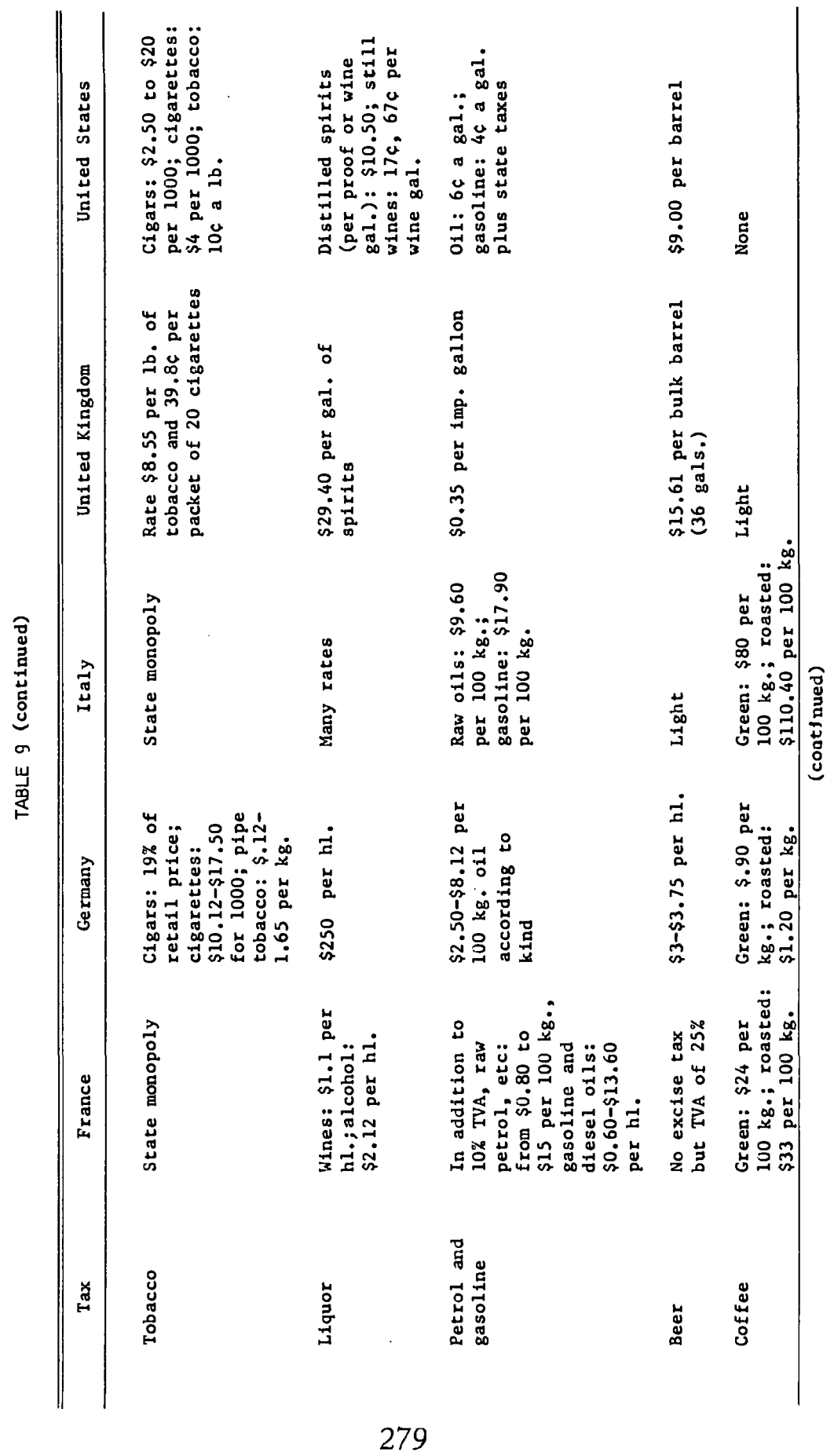


EUROPEAN TAX SYSTEMS

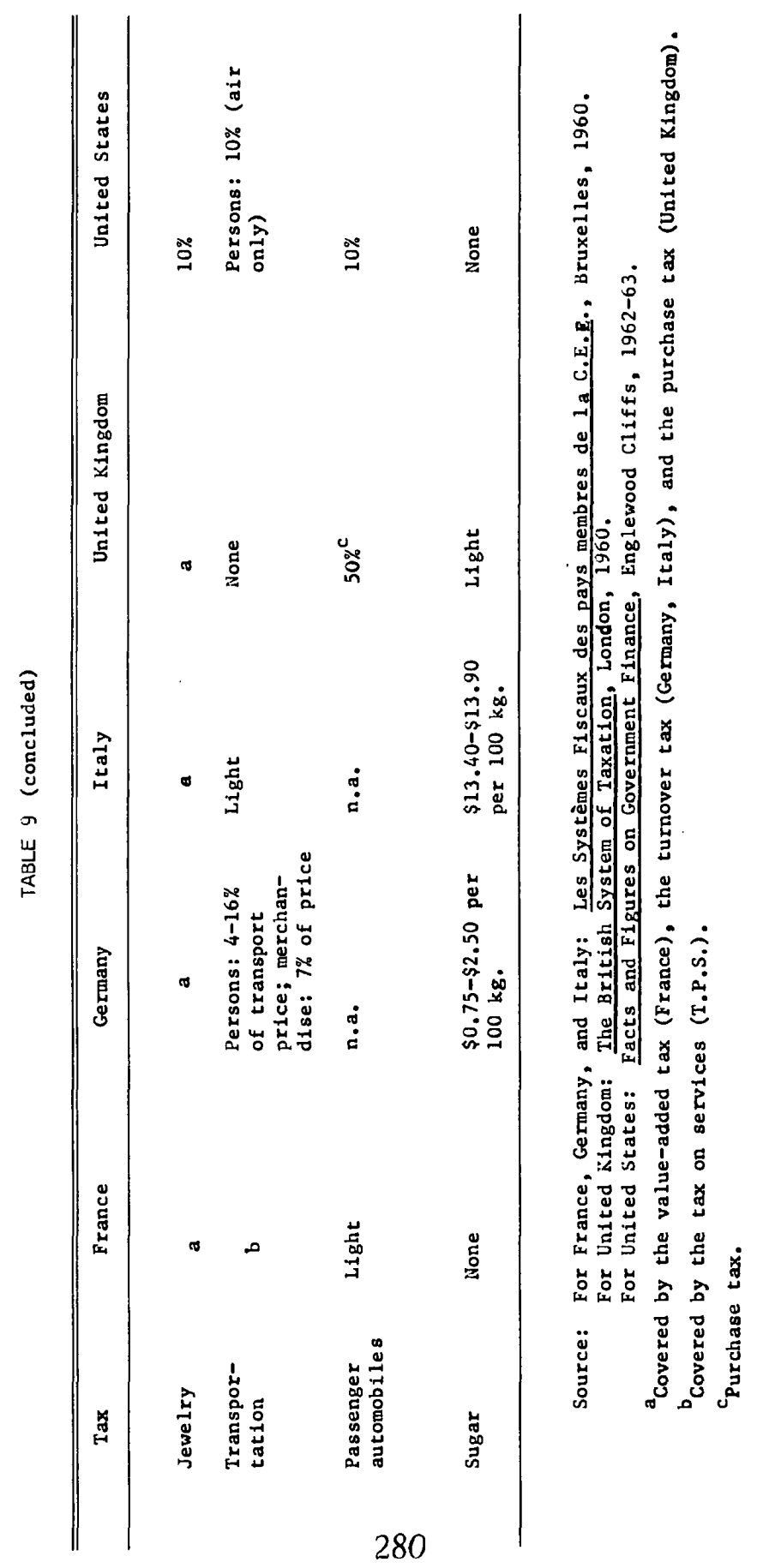




\section{EUROPEAN TAX SYSTEMS}

TABLE 10

DETAILED FISCAL REVENUES FOR CENTRAL GOVERNMENT OF FRANCE, 1960 (million NF)

\begin{tabular}{|c|c|}
\hline $\begin{array}{l}\text { Revenues from direct contributions } \\
\text { Direct contributions collected by way of register } \\
\text { of emission } \\
\text { Taxes on societies } \\
\text { Payroll tax } \\
\text { Complementary tax }\end{array}$ & $\begin{array}{l}20,617 \\
8,781 \\
6,329 \\
4,486 \\
1,021\end{array}$ \\
\hline $\begin{array}{l}\text { Revenues from registration } \\
\text { Passage of property through sales } \\
\text { Passage of property through donation } \\
\text { Special tax on insurance contracts } \\
\text { Other revenues }\end{array}$ & $\begin{array}{r}2,486 \\
708 \\
672 \\
544 \\
512\end{array}$ \\
\hline Stamp duties & 1,054 \\
\hline Duties on stock market operations & 182 \\
\hline $\begin{array}{l}\text { Custom duties } \\
\text { Import duties } \\
\text { Internal duties on petrol products } \\
\text { Other duties }\end{array}$ & $\begin{array}{r}7,232 \\
1,336 \\
5,599 \\
297\end{array}$ \\
\hline $\begin{array}{l}\text { Revenues from indirect contributions } \\
\text { Duties on liquor, wines, ciders, etc. } \\
\text { Duties on alcohol } \\
\text { Other duties }\end{array}$ & $\begin{array}{r}1,053 \\
197 \\
663 \\
193\end{array}$ \\
\hline Taxes on transport of goods & 191 \\
\hline $\begin{array}{l}\text { Turnover taxes } \\
\text { Value-added tax (TVA) } \\
\text { Tax on services (TPS) } \\
\text { Other }\end{array}$ & $\begin{array}{r}19,559 \\
17,429 \\
2,060 \\
70\end{array}$ \\
\hline $\begin{array}{l}\text { Revenue from other commodity taxes } \\
\text { Wine and cider } \\
\text { Meat } \\
\text { Coffee and tea }\end{array}$ & $\begin{array}{r}1,978 \\
975 \\
769 \\
234\end{array}$ \\
\hline Total fiscal revenues & 54,366 \\
\hline
\end{tabular}

Source: Direction de la Comptabilite Publique. 


\section{EUROPEAN TAX SYSTEMS}

TABLE 11

FISCAL REVENUE FOR FEDERAL GOVERNMENT, LÄNDER, AND COMMUINITIES OF GERMANY, 1960

(million DM)

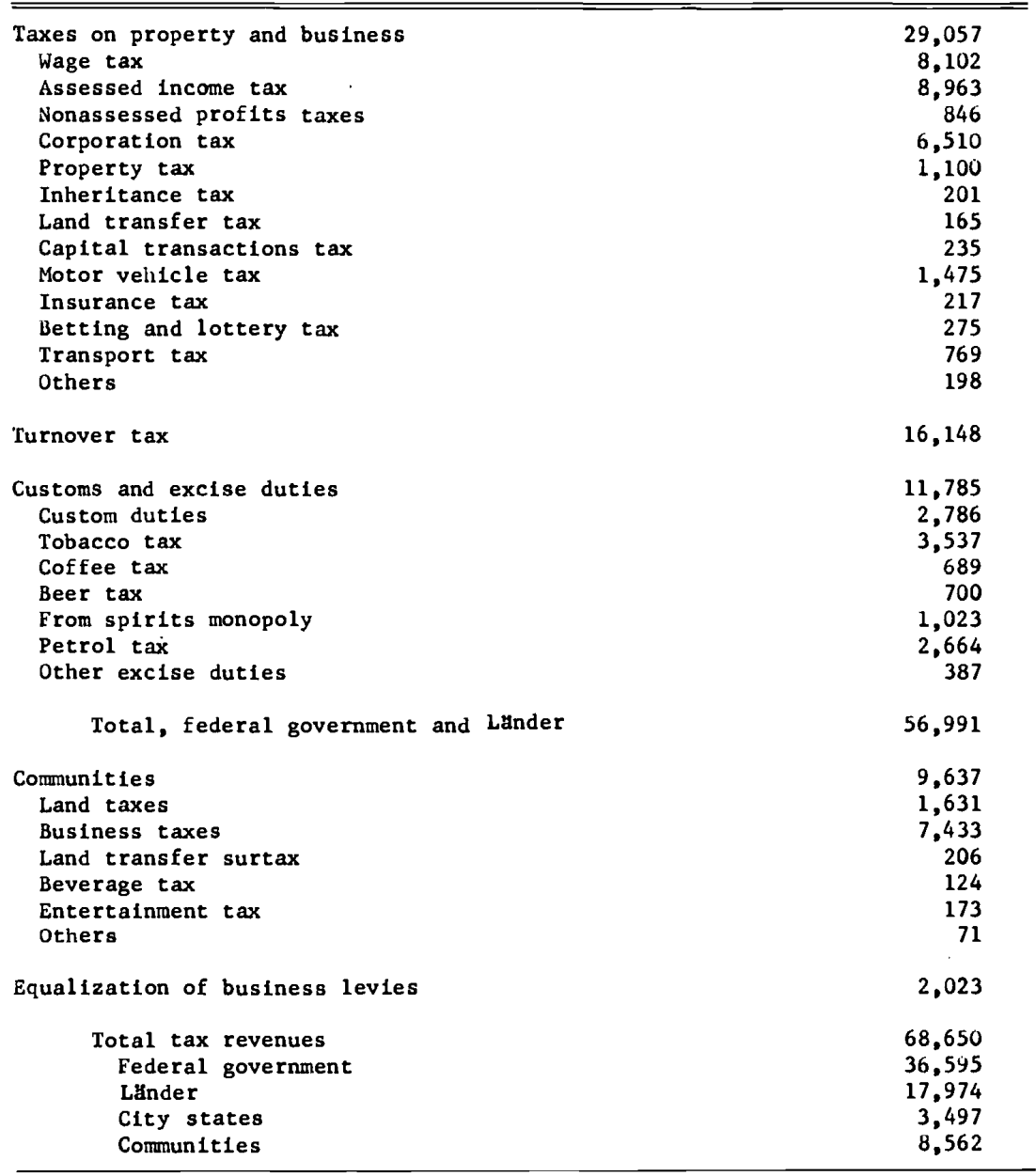

Source: Statistisches Jahrbuch, 1961. 


\section{EUROPEAN TAX SYSTEMS}

TABLE 12

FISCAL REVENUES FOR CENTRAL GOVERNMENT OF ITALY, 1961

(milition lire)



Source: Annuario Statistico Italiano, Istituto Centrale di Statistica, Rome, 1961. 


\section{EUROPEAN TAX SYSTEMS}

TABLE 13

TAXES ON INCOME AND CAPITAL AND NATIONAL INSURANCE CONTRIBUTION, BY TYPE OF INCOME, PROPERTY, AND SECTOR, UNITED KINGDOM, 1960 (mi111on pounds)

\begin{tabular}{|c|c|}
\hline $\begin{array}{l}\text { Taxes on income (payments) } \\
\text { Persons } \\
\text { Companies } \\
\text { Public corporations }\end{array}$ & $\begin{array}{r}2,020 \\
693 \\
12\end{array}$ \\
\hline National insurance and health contributions & 911 \\
\hline Total & 3,636 \\
\hline $\begin{array}{l}\text { Rent of } 1 \text { and and bulldings } \\
\text { Income tax } \\
\text { Surtax }\end{array}$ & $\begin{array}{r}129 \\
4\end{array}$ \\
\hline $\begin{array}{l}\text { Transfer Income } \\
\text { Income tax }\end{array}$ & 16 \\
\hline $\begin{array}{l}\text { Dividends, interest, and trading incomes } \\
\text { Income tax } \\
\text { Surtax } \\
\text { Profits, excess profits tax, excess profits levy, etc. } \\
\text { Insurance contributions of self-employed and non- } \\
\quad \text { employed persons }\end{array}$ & $\begin{array}{r}1,027 \\
118 \\
262 \\
48\end{array}$ \\
\hline $\begin{array}{l}\text { Income from employment } \\
\text { Wages and salaries } \\
\text { Income tax } \\
\text { Surtax } \\
\text { Employees' insurance contributions }\end{array}$ & $\begin{array}{r}1,087 \\
55 \\
431\end{array}$ \\
\hline $\begin{array}{l}\text { Pay of the forces } \\
\text { Income tax } \\
\text { Surtax } \\
\text { Employees' insurance contributions }\end{array}$ & $\begin{array}{r}26 \\
1 \\
8\end{array}$ \\
\hline $\begin{array}{l}\text { Employers' Insurance contributions } \\
\text { Forces } \\
\text { Civilian employers }\end{array}$ & $\begin{array}{r}11 \\
413\end{array}$ \\
\hline Tota1 & 3,636 \\
\hline $\begin{array}{l}\text { Taxes on capital } \\
\text { Death duties: } \\
\text { Land and buildings } \\
\text { Government and municipal securities } \\
\text { Other stocks and shares } \\
\text { Other forms of property }\end{array}$ & $\begin{array}{r}35 \\
48 \\
109 \\
44\end{array}$ \\
\hline Total & 236 \\
\hline
\end{tabular}

Source: National Income and Expenditure, Central Statistical office, London, 1961. 


\section{EUROPEAN TAX SYSTEMS}

TABLE 14

TAXES ON INCOME, CAPITAL, EXPENDI TURES, AND OTHER REVENUES OF CENTRAL GOVERNMENT, UNITED KINGDOM, 1960

(million pounds)

\begin{tabular}{|c|c|}
\hline $\begin{array}{l}\text { Taxes on income } \\
\text { Income tax } \\
\text { Surtax } \\
\text { Profits tax } \\
\text { Excess profits tax, excess profits levy, etc. }\end{array}$ & $\begin{array}{r}2,725 \\
2,285 \\
178 \\
260 \\
2\end{array}$ \\
\hline $\begin{array}{l}\text { Taxes on capital } \\
\text { Death duties } \\
\text { Special contributions }\end{array}$ & $\begin{array}{r}236 \\
236 \\
--\end{array}$ \\
\hline $\begin{array}{l}\text { Taxes on expenditures } \\
\text { Customs and excise duties } \\
\text { Beer } \\
\text { Wines and spirits } \\
\text { Tobacco } \\
\text { Hydrocarbon oils } \\
\text { Protective duties } \\
\text { Purchase tax } \\
\text { Entertainment } \\
\text { Betting } \\
\text { Other }\end{array}$ & $\begin{array}{r}2,641 \\
2,387 \\
220 \\
180 \\
818 \\
400 \\
154 \\
531 \\
2 \\
41 \\
41\end{array}$ \\
\hline $\begin{array}{l}\text { Motor vehicle license duties } \\
\text { Transport levy } \\
\text { Stamp duties } \\
\text { Post office surplus } \\
\text { Broadcast license revenue retained by exchequer } \\
\text { Miscellaneous }\end{array}$ & $\begin{array}{r}123 \\
-- \\
94 \\
5 \\
5 \\
27\end{array}$ \\
\hline $\begin{array}{l}\text { Other revenue } \\
\text { National insurance and health contributions } \\
\text { Gross trading income } \\
\text { Gross rental income } \\
\text { Interest and dividends } \\
\text { Current grants from overseas governments }\end{array}$ & $\begin{array}{r}911 \\
125 \\
70 \\
339 \\
-\end{array}$ \\
\hline Total & 7,047 \\
\hline
\end{tabular}

Source: National Income and Expenditure, Contral Statistical Office, London, 1961.

\section{COM MEN T}

Fritz Neumark, Goethe University, Frankfurt/Main, and Columbia University

Since, on the one hand, my time is very short and, on the other, I am hampered by my imperfect knowledge of your language, the praisecriticism ratio of my comments on Eckstein's paper will be unduly low.

I think, however, that the author has done an excellent job and I 
agree with most, though not all, of his conclusions as well as with the essence of his factual summary of European tax system structures. His task (which he himself calls quite correctly "treacherous") was by no means an easy one. Anyone who has tried to draw an exact picture of the character and effective distribution of tax burdens in foreign countries will be aware of this.

In particular, I share Eckstein's view that many critics of the present U.S. tax structure have fallen prey to statistical fallacies which have led them to exaggerate the structural differences between the European and American tax systems; it is one of the greatest merits of the paper that it has revealed and corrected these errors. I find myself in agreement also with the author's statement that most European countries are not a "tax paradise" and that they did not achieve their combination of strong economic growth and full employment by fiscal measures alone.

As to my critical comments, some of them are of a general and theoretical nature but most of them refer to empirical questions. First of all, I would like to say a few words on a point which seems to me of predominant importance to the topic of this conference, namely, the distinction between so-called direct and indirect taxes. There are several possibilities of establishing scientifically satisfactory classifications of taxes and William Fellner is certainly right in saying that classification always includes an element of arbitrariness. But if one wants to maintain the time-honored distinction between direct and indirect taxes, it has to be based on a clear-cut, unequivocal criterion. The traditional distinction has been based upon tax shifting; unfortunately the extent to which various taxes shift is not known. For example, a corporation tax may or may not be shifted forward. Thus shiftability does not represent a quality of only one group of taxes; there are obviously many exceptions to the general rules. Some persons confine themselves to an enumeration of taxes which they assign to each group without any clear-cut distinguishing criterion. This applies, for example, to Eckstein's classification of property taxes as "indirect." $\mathrm{He}$ also includes employer contributions to social security in the indirect tax group, considering them as "costs of carrying on business like any other tax on the use of a factor of production; even if they are shifted to the employee, he will not recognize them nor view them as a direct payment out of his income." Here it seems that Eckstein refers at first to shiftability but since he is not certain of its usefulness, he adds the "inconspicuousness" criterion. However, this has lost much of its former importance because of changes in fiscal techniques and various other factors. Thanks to the efforts of 
newspapers, trade unions, etc., to enlighten people, present-day taxpayers are not as uninformed about the relations between excise duties and consumer goods prices as their ancestors were. Withholding of income tax at the source, on the other hand, has lessened taxpayer awareness of this levy, so that as long as there are no substantial changes in effective tax burdens, the average taxpayer considers only the "takehome pay." From the point of view of democracy, it is a debatable issue whether unawareness on the part of taxpayers of their burdens is desirable.

A second general remark is that Eckstein throughout his paper neglects the effects of the disbursement side of the taxation process, in other words, public expenditures. It can be argued that in developed countries the direct versus indirect tax controversy must take into account the fact that in the course of the last several decades, the distribution of benefits derived from public expenditures has changed in such a way as to offset or more than offset the regressive effects of excise duties and possibly of general sales taxes. This statement, however, is of greater relevance for most European countries than for the United States.

My third general remark is not intended to contradict Eckstein's conclusions but rather to amend them on one point. As he mentions, it is of ten thought in this country that the astounding European economic recovery and growth - to the extent that they can be ascribed to fiscal measures-were due mainly to a high share of indirect taxation in the over-all tax structure, relative to that in the United States. However, it seems to me that on the whole, and particularly in France, Germany, and Italy, differentials within the system of direct taxation had at least an equal, and probably an even greater, importance for high saving and investment rates that furthered growth. I refer particularly to low tax rates and partial exemptions provided for retained profits used for reinvestment, on the one hand, and special allowances for personal savings, on the other.

My next group of comments is on statistical and factual questions. Eckstein, of course, is quite aware of the fact that tax statistics, if confined to central governments alone, lead to erroneous conclusions since the shares of the different levels of government in over-all government finance vary considerably. Nevertheless, his paper contains several tables showing only central government figures. I would prefer to omit such data since they are likely to be misused for political purposes. The differences are clearly demonstrated in Eckstein's Table 11. The importance of the German corporation tax for central government reve- 
nues appears to be only half that of the French tax, whereas with all levels of government the share of the German tax is much higher than that of the French one-in fact even more so than the OEEC data quoted by Eckstein indicate.

As for his Table 6, the figures on the German personal income tax are not exactly correct. For example, the maximum marginal rate is given as 57.24 per cent, whereas it is actually 53 per cent. Even if one adds the so-called church tax (generally neglected in the paper), which is a 10 per cent supplement to income tax, the marginal rate mentioned by Eckstein is still not quite correct. Besides, it is not clear whether the exemptions shown in the table include, in addition to personal allowances, lump-sum deductions for Werbungskosten, and for so-called "special expenses." If both of these deductions are taken into account, German income tax exemptions rise from $\$ 1560$ to $\$ 1785$.

Somewhat more important is the fact that Eckstein's view that in Europe "capital gains are not taxed at all unless they originate from a personal business" is not quite correct. As a matter of fact, in Germany, capital gains are taxed at normal income tax rates provided they are short-term gains, i.e., gains realized on securities held less than six months, or real estate held less than two years.

On the question of evasion, I would like to add the following remark. Eckstein mentions that countries with a Latin tradition such as France and Italy are generally believed to have extensive evasion. He then presents some figures which, in his opinion, show that "the deviations are not as large as is often suggested." These figures, however, do not seem to me to be very conclusive. First of all, they show that the ratio of personal direct taxes to national income in France is only half the corresponding German ratio, and the Italian one-half that in United Kingdom; these are rather important differences. Second, it is not clear whether in Table 8 Eckstein includes among French "direct taxes" the versement forfaitaire (payroll tax paid by employers) as he does in Table 2. In this latter table, he does not take into account the German Gewerbesteuer which at least partly corresponds to the French tax. Third, in an earlier section of his paper, the author very correctly points out that "the actual burden of taxation depends not only on the letter of the law . . . but also on the spirit of compliance and enforcement" and that "a perfect comparison can only be obtained by living under each of the tax systems and by dealing with each of the tax collectors." Although in principle this is true, I believe that information gathered from official reports as well as from private sources suffices to prove 


\section{EUROPEAN AND U.S. TAX STRUCTURES}

that in fact, the "propensity to evade" of-let us say-Mediterranean taxpayers is much higher than that of Anglo-Saxon and Scandinavian taxpayers.

With respect to estate and gift taxes, Eckstein quotes the data given by Nortcliffe in his well-known book, Common Market Fiscal Systems. These data are not correct. Under the assumptions made by the author, the German tax burden amounts not to 10 per cent but to more than 12 per cent. ${ }^{1}$

A further point refers to the German Gewerbesteuer and similar taxes in France. I could not tell if Eckstein classified these taxes as direct or indirect. This is important because the German trade tax (as Eckstein calls it) is a rather heavy burden on business. Its yield according to Eckstein is "equal to the corporation tax." This is an understatement. Ever since 1953, the Gewerbesteuer has raised more revenue than corporation income tax; estimates for 1963 are 9.26 and 8.46 billion DM, respectively. Also, the paper gives some data on the trade tax (which it rightly describes as the main source of revenue of municipalities) that may lead the reader to false conclusions. On the one hand, the rates mentioned are not general, uniform rates but rather weighted averages of the various local rates. On the other hand, they give the impression that the trade tax is universally assessed on profits, net worth, and wages paid, whereas, in fact, the payroll tax is not an obligatory element of the system and is collected only in a few-though rather importantcommunities.

My last special remark relates to Eckstein's comments on the use of selective devices. About Germany he says that "before 1950, selective devices were used" whereas after that year, "the emphasis changed from selective devices toward general rate reduction." This statement is not entirely correct. It is true that tax reforms after 1953 tried to abolish step by step the special depreciation allowances, exemptions, rate differentials, etc., and to replace them by a series of rather substantial tax cuts which lowered the maximum marginal income tax rate from 95 to 53 per cent. However, due to the strong influence of pressure groups, the German government did not succeed in abolishing all the selective devices just mentioned. In fact, in the course of the last years, some new differentials were inserted not only in the income and corporation tax laws but also in the turnover tax.

${ }^{1}$ In this connection, I would like to stress an error to be found in the appendix to Eckstein's paper prepared by Vito Tanzi. The minimum exempted from the German inheritance tax for a surviving spouse is given as $30,000 \mathrm{DM}$. In most cases, however, it is $250,000 \mathrm{DM}$. 
To complete the review of the picture drawn in the paper of Germany's postwar tax policy, I would like to stress the following two points. First, Germany has made tax cuts not only in direct but also in indirect taxation. This is true of excise duties on tobacco, coffee, tea, champagne, etc. Second, the progressive lowering of nominal and effective tax rates for the purpose of stimulating economic growth was a necessary condition for the uninterrupted rise in fiscal revenue. Between 1954 and 1963, tax revenues of all levels of government rose from 38.3 to 92.1 billion DM, and since 1959 the growth rate of tax yields has exceeded that of GNP-in fact, the former rate averaged 14 per cent between 1959 and 1961 compared to a GNP growth rate of 10.1 per cent. These figures reflect the considerable built-in flexibility of the German tax system, due primarily to personal income taxation. During the last decade (1953-63), revenue from the personal income tax rose from 8.6 to 27.7 billion DM (222 per cent), representing percentages of the tax total of 23.5 and 30.1, respectively. Compared to this, the yield of the turnover tax-the second pillar of the German tax system-rose from 8.9 to 20.2 billion DM (127 per cent), but its relative importance declined from 24.2 to 22 per cent; this is all the more remarkable as, in contrast to the income tax rates, the general turnover tax rate remained unchanged. Thus the turnover tax proved to be a relatively weak automatic stabilizer.

Finally, I would like to raise the following points. As is stressed in Eckstein's paper, structural differences between most European tax .systems and the American system will become rather small if and when U.S. income taxes are reduced as proposed by the Kennedy administration. However, probably no modern state can do without some general sales taxation. For the time being, the U.S. federal government is in a position which permits it to refrain from using such taxes. On the other hand, sales taxation is already used in a majority of the states as well as in some municipalities. Most local tax revenue stems from property taxes, which in some cases imply a debatable and one-sided tax burden distribution. Therefore I would like to recommend an intergovernmental tax reform which would provide the sharing of sales tax revenues in order to allow a reduction in property tax rates.

\section{Dan Throop Smith, Harvard University}

Eckstein has given us his usual incisive and thoughtful analysis. His general appraisal of the significance, and lack of significance, of the general characteristics of the European tax system for the rate of growth 
seems reasonable. One would be quite unlikely to find conclusive evidence of the effects of taxation on economic growth in view of all the other relevant factors. This is especially so when the attributes of the tax system are divided into such broad and nonhomogeneous categories as direct and indirect taxation.

The dissimilar economic consequences of various forms of taxation within the two broad categories is recognized by Eckstein, both explicitly and implicitly, but emphasis on the nature of the probable differing effects of different taxes within the broad categories appears more useful than an analysis of definitions or possible modifications of the statistics.

Employees' contributions to social security funds and top-bracket individual income taxes are both classified as direct taxes, but they seem likely to have quite different effects on effort, on savings, on investment, and on the demand for specific consumer goods. They may even have a different incidence; if wage demands are geared to take-home pay, a rise in social security contributions may lead to pay increases which would not otherwise occur.

The high proportion of social security expenditures financed by general revenues in the United Kingdom is notable. It is not clear, of course, what particular forms of taxation are made correspondingly higher than they otherwise would be, but it seems likely that a good deal of the burden must fall on income or profits taxes. Employee contributions, on the one hand, and income and profits taxes, on the other, would all be considered as direct taxes and not differentiated in a general statistical summary, though their probable impacts seem quite different. Eckstein's paper, with Tanzi's appendix, does give the necessary breakdowns, including rate scales for income taxation.

I would urge that further analysis be made of the probable significance of some of the very important differences within the broad categories. Sometimes even apparent similarities may conceal important differences. It is stated, for instance, that the effect of the withholding presumption of the British income tax applicable to corporations and the gross-up on dividends is to leave only the profits tax as the net tax burden on distributed profits. With a 15 per cent profits tax rate, this gives the same rate as in Germany. But this is an apparent similarity with, I suggest, a profound difference.

In Germany, the corporation pays a lower rate by distributing some of the income; in Great Britain, the full income tax rate applies to all corporate income regardless of its distribution, and the statistical conclusion of a low net rate on distributed profits is based on the credit 
against personal tax allowed at the stockholder level. In terms of management attitudes toward distribution, stockholder pressures for distribution, and availability of corporate funds for expansion, these two approaches are altogether different. The inherent differences in structure seem much more significant than the statistical similarities.

Differences in depreciation allowances and other investment credits or allowances seem particularly important in an analysis of tax influences on capital formation. The general absence of anything like the reserve ratio test in Europe is a significant fact in making the relatively high authorized depreciation rates available without restraint. The fact that depreciation must be taken on a company's books if it is to be allowed for tax purposes on the continent (though not in Great Britain) is not the restrictive factor which it might be here in view of the relatively lax accounting standards on the continent and, more particularly, the tradition of showing profits only slightly in excess of dividends.

The statement that depreciation in France is based on original cost, though perhaps technically correct, is completely incorrect in its implication because it ignores the application to cost and to past depreciation charges of a multiple starting at 243 for 1914 and previous years and descending to 1.05 for 1958 . The operation of this multiple has permitted additional depreciation to reflect past inadequacies, due to inflation, on property previously fully depreciated. This has been a very important factor in permitting self-financing of new investment.

The provision in the French law which permits the balancing charge (that is, the gain on sale of depreciated assets to the extent of previous depreciation) to be applied in a very generous fashion to reduce the basis of newly acquired assets as an option to current taxability also seems worthy of attention in an analysis of tax influences on investment. Such technical tax matters as these in the nature of one item in the direct-tax category seem much more important than debate about the definition of direct taxation or statistical refinement in the comparison of direct and indirect taxation.

Indirect taxation also covers a vast range of taxes with quite dissimilar economic effects, as is immediately apparent if one considers the relative significance of taxation on alcohol, buildings (with perhaps further attention to the dissimilar treatment of industrial and residential property and of new and old buildings), and electric power. The detail seems more important than the aggregate, or rather the aggregate is almost meaningless without the detail.

Here again, what may seem like technical differences may be tre- 
mendously important. I have time to mention only one. The presentation on the value-added tax does not recognize the two possible ways of treating the tax component in purchased capital equipment-immediate deduction, which may wipe out completely the value-added tax due by a company which is expanding fairly rapidly, and amortization over the probable life of the equipment. The former method is used in France as a matter of economic policy. The value-added tax is now being extended through the retail stage, to take the place of the present 2.75 per cent tax on retailing, with the expectation that it will encourage investment, improve efficiency, and reduce cost in distribution.

The alternative method of amortization is, I believe, the one contemplated in Germany. It conspicuously fails as an inducement for investment. In Great Britain the French method is, fortunately, tacitly assumed to be the method to be used by those discussing the possible substitution of a value-added tax for the profits tax. The difference in method of treating the tax included in the price of capital equipment under this one form of tax seems much more significant than a difference of even several percentage points in the proportionate yield of direct and indirect taxation. As a final point, the fact that the value-added $\operatorname{tax}$ can be rebated on exports under its GATT agreements, 'while income and profits taxes cannot, seems worthy of recognition in the discussion of its possible significance for the United States.

My general conclusion from reflection on the subject of this Conference is that the traditional distinction between direct and indirect taxation which I, along with so many others, have made in the past obscures so many important differences that it may be meaningless and even misleading. The problem is not primarily a statistical one, however. We need to examine the nature of the various taxes within these broad categories and even some rather technical aspects of the specific taxes to determine their economic significance. 
